\section{Biogeochemistry}

May 2008, Volume 88, Number 3, Pages 213-231

http://dx.doi.org/10.1007/s10533-008-9199-2

(c) 2008 Springer. Part of Springer Science+Business

Media

The original publication is available at http://www.springerlink.com
Archimer, archive institutionnelle de l'Ifremer http://www.ifremer.fr/docelec/

\title{
Phosphorus dynamics and bioavailability in sediments of the Penzé Estuary (NW France): in relation to annual P-fluxes and occurrences of Alexandrium Minutum
}

\author{
F. Andrieux-Loyer ${ }^{1,{ }^{*}}$, X. Philippon ${ }^{1}$, G. Bally ${ }^{1}$, R. Kérouel ${ }^{1}$, A. Youenou ${ }^{1}$ and J. Le Grand ${ }^{1}$ \\ ${ }^{1}$ DYNECO Pelagos, IFREMER, B.P. 70, 29280 Plouzané, France \\ *: Corresponding author : F. Andrieux-Loyer, email address : Francoise.Andrieux@ifremer.fr
}

\begin{abstract}
:
The macrotidal estuary of Penzé (Brittany, Western part of the Channel, France) has been subjected to recurrent annual toxic blooms of Alexandrium minutum since 1988. This study aims to specify the phosphorus dynamics and bioavailability in sediments in order to improve our understanding of Alexandrium occurrences. Sediment-P pools and diffusive phosphate fluxes were studied under similar hydrodynamic conditions, in the intermediate estuary in May, June and July 2003 and along the salinity gradient from August 2004 to June 2005. The results highlight a decrease in bioavailable phosphorus (iron and organic bound) from the inner part of the estuary seaward. The ratio of ironbound phosphorus to iron-oxyhydroxides is lower in the inner and intermediate estuaries (5-8) than in the outer site (15), suggesting a saturation of sorption sites and greater phosphorus bioavailability in this area. Pools of bioavailable phosphorus in surficial sediments are about eight times higher than the annual net-export of $P$ ( 7 ton year-1). Phosphate releases from sediments are always lower than 5 umol m-2 d-1 in March. The highest supplies occur in June and August in the intermediate area (up to $400 \mu \mathrm{mol} \mathrm{m}-2 \mathrm{~d}-1$ ) where they represent up to $50 \%$ of river loadings. These results further suggest that phosphate pulses coincide with occurrences of Alexandrium reported in June.
\end{abstract}

Keywords: Alexandrium minutum - Estuary - Phosphate fluxes - Pore water - Sediment phosphorus Sequential extraction 


\section{Introduction}

Estuaries are generally regarded as highly eutrophic systems as a result of anthropogenic nutrient inputs. Among the many compounds usually supplied into the rivers and estuaries, phosphorus is important due to its buffering mechanism. The buffering mechanism of $P$ is known for maintaining its concentrations close to constant values, providing an additional potential reservoir for primary production (Smil, 2000). Moreover, in such productive areas, sediments receive high concentrations of organic matter due to shallow water depths and river inputs. After sedimentation, organic particles are subjected to a continuous degradation and mixing process. The sediment may act as a phosphorus sink, thus liberating phosphate under specific conditions. This phenomenon is attributed mainly to the $\mathrm{Fe}$ (III)-bound-P dissolution when conditions change from oxic to anoxic, to the desorption of adsorbed phosphate when fine particles are resuspended (Froelich, 1988; Aminot et al., 1993; Andrieux and Aminot, 1997; Andrieux-Loyer and Aminot, 2001) and to the assimilation of organic phosphorus by the bacterial community (Clavero et al., 1999b; Avilés et al., 2005). The released $P$ may significantly increase the biologically available pool of $P$ in the water, counteracting decreases in the external loads. As an illustration, in some estuaries, intrinsic supplies of phosphate by desorption, reduction or mineralization, may exceed external supplies by a factor 2 to 4 due to high concentrations in sediments (Schlungbaum and Nausch, 1990). Therefore, the knowledge of sedimentary phosphorus speciation and phosphate fluxes is essential in every study which aims to understand the functioning of a coastal system under anthropological constraints.

The Penzé estuary (North of Brittany, France) has been subjected to recurrent annual toxic blooms of the dinoflagellate Alexandrium minutum since 1988 (Erard-Le Denn, 1997). The conditions leading to the development of Alexandrium minutum (hydrology and nutrient concentrations) have been fairly well studied (Maguer et al., 2004). The efflorescences reappear evenly under specific conditions (neap tide, temperature over $16{ }^{\circ} \mathrm{C}$, and salinity between 26 and 28). However, the role of sediments in nutrient dynamics controlling the primary production is still poorly documented. Laboratory experiments on Alexandrium minutum growth control and one of its competitors -Heterocapsa triquetra- showed that Alexandrium minutum was only predominated in mixed culture when deprived of phosphate for 5 days and then subjected to a phosphate supply (Labry et al., in press). It is therefore essential to verify if the sediment could potentially generate such phosphate supplies in the water column.

This study aims to point out the phosphorus dynamics and bioavailability in sediments in order to improve our understanding of Alexandrium minutum occurrences. To this end, seasonal variations of diffusive phosphate fluxes and phosphorus forms were studied along the salinity gradient. With these data we intend to answer two questions: (1) to what extent can the phosphorus sedimentary stock counterbalance a reduction in phosphate external loadings to prevent the bloom from fully developing, (2) to what extent can benthic fluxes contribute to phosphate enrichment of the water column.

\section{Materials and methods}

\subsection{Study site}

The Penzé River (28 km in length) drains an area of about $151 \mathrm{~km}^{2}$ in North Brittany (figure 1a). The activities around the catchment area are essentially agricultural. This river has three major tributaries: the Coat Toulzac'h, the Eon and the Traon Gall. Its estuary is situated between the village of Penzé and the Morlaix Bay, covering a distance of $10 \mathrm{~km}$ (figure $1 \mathrm{~b}$ ). At high tide, the width of the channel is about $100 \mathrm{~m}$, whereas at low tide, fresh waters go through a narrow channel about $10 \mathrm{~m}$ wide. The axis of the channel, the bottom of which consists of gravel, is situated between two muddy banks. The Penzé estuary is subjected to a macrotidal regime and the tidal range fluctuates between $1.8 \mathrm{~m}$ and $9.2 \mathrm{~m}$. The water discharge at the village of Penzé ranges from $0.4 \mathrm{~m}^{3} \mathrm{~s}^{-1}$ in summer to $15 \mathrm{~m}^{3} \mathrm{~s}^{-1}$ in winter. Since 1989, nutrient measurements have shown a high nitrate content $\left(768 \pm 192 \mu \mathrm{mol} \mathrm{I}^{-1}\right)$ and lower concentrations in ammonium $\left(14.3 \pm 12.3 \mu \mathrm{mol} \mathrm{I}^{-1}\right)$, phosphate $\left(5.4 \pm 3.3 \mu \mathrm{mol} \mathrm{I}^{-1}\right)$ and silicate $\left(185 \pm 23 \mu \mathrm{mol} \mathrm{I}{ }^{-1}\right.$; data from ECOFLUX, 2007). Water temperature in this system varies usually from $8{ }^{\circ} \mathrm{C}$ in winter to $20^{\circ} \mathrm{C}$ in summer (Waeles, 2005). 


\subsection{Sampling}

Samples were collected during the early summer 2003 in the intermediate estuary (st X) and from August 2004 to June 2005 along the salinity gradient (seven stations, from st A to st F plus st X). One core was sampled at each station except in May and July 2003 where samplings were duplicated. This study was carried out during similar hydrodynamic conditions (low river flow, neap tide, ebb tide). A parallel survey during a tidal cycle (June 2005) in the intermediate estuary (st X) showed that the highest phosphate diffusive fluxes occurred during neap tide (Bally et al., in preparation). A summary of overlying physical-chemical water properties is given in table 1.

Sediment and its overlying water were collected by hand corer using PVC cores (id $=9 \mathrm{~cm}$; $\mathrm{h}=30 \mathrm{~cm}$ ), as described in Mudroch and Azcue (1995). Any disturbance of the sediment-water interface was carefully avoided.

\subsection{Overlying and pore water treatments}

Overlying water was collected immediately after core recovery for further nutrient analyses. The profiles of pore-water oxygen were then measured using a miniaturized Clark-type oxygen sensor (Unisense OX500) coupled with a picoammeter (Unisense PA2000) and a micromanipulator (Unisense MM33). Oxygen profiles were only performed in March and June 2005 as the sensors were not available in August and December 2004. The in-situ temperature was maintained by using an insulating device.

Subsequently, the core was sliced into sixteen horizontal layers up to a total depth of $20 \mathrm{~cm}(0.5 \mathrm{~cm}$ for the top $3 \mathrm{~cm}, 1 \mathrm{~cm}$ up to $8 \mathrm{~cm}, 2 \mathrm{~cm}$ below, and $3 \mathrm{~cm}$ at the bottom) within 30 min. For every level, a sub-sample was centrifuged in a Whatman VectaSpin 20TM centrifuge tube filter $(0.45 \mu \mathrm{m})$ under inert atmosphere $\left(\mathrm{N}_{2}\right)$ at $3000 \mathrm{rpm}$ and $4{ }^{\circ} \mathrm{C}$ for $20 \mathrm{~min}$ in order to collect pore waters. The pore water was acidified to $\mathrm{pH} \sim 2$. An aliquot was frozen for further nutrient analysis. Another aliquot was maintained at $4{ }^{\circ} \mathrm{C}$ for $\mathrm{Fe}^{2+}$ and $\mathrm{Mn}^{2+}$ analysis.

\subsection{Sediment treatments}

An aliquot of the wet sediment of known volume and weight was dried (5 days) and the weight loss was used to calculate porosity (Berner, 1980). Another sample was maintained at $4{ }^{\circ} \mathrm{C}$ for less than 15 days for sediment grain size determination. Finally, a sub-sample of wet sediment was frozen for the subsequent organic $C$ analysis. Porosity, grain size and carbon determinations were only performed on the first three centimeters (6 layers), except in August when the whole core was analysed. The sediment remaining after the collection of the pore water was frozen at $-25{ }^{\circ} \mathrm{C}$ for phosphorus speciation.

\section{Sequential extraction of phosphorus pools and analysis}

The major reservoirs of sedimentary $\mathrm{P}$ were determined using the widespread sequential method of Ruttenberg $(1990,1992)$. The main features are presented in table 2.

There are three differences compared to the original procedure of Ruttenberg (1992). Firstly, exchangeable $\mathrm{P}$ (Exch-P) was not extracted in step I with $\mathrm{MgCl}_{2}$ but separately using the infinite dilution extrapolation (IDE) method (Aminot \& Andrieux, 1996). Thus, step I extraction in this study includes easily exchangeable $\mathrm{P}$ and iron oxide-bound $\mathrm{P}$ (Fe-P). Secondly, we omitted citrate in the first step as it was shown to make a part of the calcium-bound phosphate soluble (Psenner, 1988). Thirdly, the $\mathrm{MgCl}_{2}$ and $\mathrm{H}_{2} \mathrm{O}$ washes were omitted except in the acetate buffer treatment (step II). These were originally used to avoid the secondary sorption of $P$ on the residual solid surfaces during the extractions. This process was shown to be insignificant in the Citrate-Dithionite-Bicarbonate (CDB) and $\mathrm{HCl}$ extractions (Ruttenberg, 1992).

Organic $\mathrm{P}$ (Orga-P) was determined nonsequentially as the difference between $1 \mathrm{M} \mathrm{HCl}$ extractable $\mathrm{P}$ $(24 \mathrm{~h})$ before and after the ignition of the sediment $\left(550{ }^{\circ} \mathrm{C}, 4 \mathrm{~h}\right.$; Aspila et al., 1976). Total $\mathrm{P}$ is calculated as the sum of this organic $\mathrm{P}$ and the inorganic $\mathrm{P}$ determined with the sequential procedure (Slomp, 1996a). The inorganic $\mathrm{P}$ concentrations determined as the sum $\mathrm{P}$-forms (Fe-bound $\mathrm{P}$, authigenic $P$ and detrital Ca-P) agreed well $\left(r^{2}=0.99 ; n=379\right)$ with inorganic $P$ concentrations obtained with the $1 \mathrm{M} \mathrm{HCl}$ extraction in the one-step procedure.

The sedimentary inorganic carbon was removed with phosphoric acid (Cauwet, 1975) before organic carbon analysis. 
The analysis of sediments for major elements (Total $\mathrm{Fe}$ and $\mathrm{Ca}$ ) was performed by the Centre de Recherches Pétrographique et Chimique (CRPG/CNRS). The sample was dissolved by fusion with $\mathrm{LiBO}_{2}$ and $\mathrm{HNO}_{3}$. These results are not shown in the present study as they are just used in a relation between $\mathrm{Ca}$ and Ca-P (see $\S \mathrm{IV} .1$ ) and in a relation with fine fraction (see § IV.2).

\subsection{Analytical procedures}

The analysis of sediment grain size was performed using LS 200 Beckman Coulter laser granulometry. Organic $\mathrm{C}$ was measured using a vario EL-III CN elemental analyser. Total Fe and $\mathrm{Ca}$ in sediments were measured by ICP-emission.

After thawing, the pore water was diluted tenfold, then analyzed using segmented flow analysis (SFA) for phosphate and nitrate (Aminot and Kérouel, 2007) and for ammonium (Kérouel and Aminot, 1997). Phosphorus forms extracts were also diluted tenfold and dithionite extracts were additionally bubbled with pure $\mathrm{O}_{2}\left(30 \mathrm{ml} \mathrm{min}^{-1}\right)$ for one minute to enable phosphate determination.

$\mathrm{Fe}^{2+}$ in pore water and Fe concentrations in the Dithionite-Bicarbonate (DB) solutions were measured with the ferrozine method (Sarradin et al., 2005) and $\mathrm{Mn}^{2+}$ with the leuco-malachite green method (Resing and Mottl, 1992), both adapted for SFA. The method of standard additions was used to check for potential interferences and to correct the results accordingly. DB-extractable $\mathrm{Fe}$ is used as a measurement of $\mathrm{Fe}$ bound in $\mathrm{Fe}$ oxides. These data allow the determination of $\mathrm{Fe} / \mathrm{P}$ ratios in sediments. The analytical precision of the determinations was better than $2 \%$.

\subsection{Calculated phosphate diffusive fluxes}

Diffusive phosphate fluxes were calculated using the first Fick's law adapted for sediments (Berner, 1980): $F d=-\phi \times D s \times\left(\frac{d C}{d z}\right)(1)$, where $F d$ is the rate of efflux $\left(\mu m o l m^{-2} d^{-1}\right), \Phi$ is the sediment porosity (dimensionless) of the upper sediment sample, Ds is the bulk diffusion coefficient $\left(\mathrm{m}^{-2} \mathrm{~d}^{-1}\right)$ and $\mathrm{dC} / \mathrm{dz}$ is the concentration gradient at sediment-water interface $\left(\mu \mathrm{mol} \mathrm{m} \mathrm{m}^{-4}\right)$.

$\mathrm{dC} / \mathrm{dz}$ was calculated from linear regression on the concentration values at bottom water and just below the interface. The use of the sedimentary surface layer in the calculation of diffusive fluxes is in agreement with the fact that most organic matter decomposition takes place at or directly below the water-sediment interface (Aller, 1980; Ehrenhauss et al., 2004). Ds was corrected for tortuosity, i.e., $D_{s}=\frac{D_{0}}{\theta \times F}$, where $\theta$ is the tortuosity (dimensionless), $\mathrm{D}_{0}$ is the diffusion coefficient in water for $\mathrm{PO}_{4}^{3-}$ $\left(\mathrm{m}^{2} \mathrm{~d}^{-1}\right)$ and $\mathrm{F}$ is the formation factor $\left(F=\phi^{-2}\right.$, Manheim, 1970). The diffusion coefficient in water $\left(D_{0}\right)$ is corrected for the in situ bottom water temperatures (Li and Gregory, 1974) and the value of $\theta$ is assumed to be equal to $\sqrt{1-2 \times \ln \varphi}$ (Boudreau, 1996).

\section{Results}

As the same patterns were observed in 2003 and in 2004-2005 both for pore water and speciation results, only the 2004-2005 results are presented. Data from the 2003 surveys may be found in the 2003 IFREMER activity report (Anonymous, 2004) and in Gallioz, 2004.

\subsection{Pore water profiles}

\section{Redox sensitive species $\left(\mathrm{O}_{2}, \mathrm{NO}_{3}^{-}, \mathrm{Fe}^{2+}\right.$ and $\left.\mathrm{Mn}^{2+}\right)$}

Oxygen concentrations in the bottom waters (figure 2) declined from about $360 \mu_{\mathrm{mol}} \mathrm{I}^{-1}$ (st A) to about $200 \mathrm{~mol} \mathrm{I}^{-1}$ (st F) in March 2005. In June, concentrations varied from about $165 \mu \mathrm{mol}^{-1}$ (st B) to about $250 \mu \mathrm{mol} \mathrm{I} \mathrm{I}^{-1}$ (st A, X and D) in the inner and intermediate estuaries whereas concentrations of up to 316 and $325 \mu \mathrm{mol} \mathrm{^{-1 }}$ were observed in the outer estuary (st F and E) corresponding to a saturation of about $130 \%$. These saturations could be explained by the development of the phytoplankton community in the outer estuary (chlorophyll concentrations up to $20 \mu \mathrm{g} \mathrm{I}^{-1}$ ) which 
consumes nutrients and carbon and release $\mathrm{O}_{2}$. The concentration profiles of $\mathrm{O}_{2}$ showed a sharp negative concentration gradient presenting the sediment as a sink for dissolved oxygen whatever the season or the location. $\mathrm{O}_{2}$ was always consumed within the first millimetres below the sediment-water interface. The penetration depths of dissolved oxygen profiles, ranged from $4 \mathrm{~mm}$ (st $A, C$ ) to $8 \mathrm{~mm}$ (st $\mathrm{E}, \mathrm{F}$ ) in March and from 1-2 mm (stations C, D, E, F and X) to 5-7 mm (st A and B) in June. These shallow penetration depths can be put down to the high reactivity of these sediments and to slow replenishment of oxygen (Sundby, 2006).

$\mathrm{NO}_{3}^{-}$concentrations in the bottom waters decreased from the inner part of the estuary (st $A$ ) to the outer part of the estuary (st F) whatever the season. The lowest nitrate concentrations in the bottom waters always occurred in August for stations $A$ to $E$ (from $13 \mu \mathrm{mol} \mathrm{I}^{-1}$ at st $E$ to $418 \mu \mathrm{mol} \mathrm{I}^{-1}$ at st $A$ ) or in June for station $\mathrm{F}\left(6.5 \mu \mathrm{mol} \mathrm{I}^{-1}\right)$. The highest concentrations were observed in March for stations $A$ to $\mathrm{F}$ (from $32 \mu \mathrm{mol} \mathrm{I}^{-1}$ at st F to $744 \mu \mathrm{mol} \mathrm{I}^{-1}$ at st A) or in December for station X $\left(277 \mu \mathrm{mol} \mathrm{I}^{-1}\right)$. The top sample of the pore water profiles was always impoverished in $\mathrm{NO}_{3}{ }^{-}$in relation to the bottom water, suggesting that the sediment is a sink of nitrate for the water column. $\mathrm{NO}_{3}^{-}$dropped to concentrations close to zero below the oxic layer. However, nitrate could be sporadically present in the anaerobic part of the sediment.

No data were available for dissolved $\mathrm{Fe}$ and $\mathrm{Mn}$ in bottom waters. $\mathrm{Mn}^{2+}$ and $\mathrm{Fe}^{2+}$ pore water profiles indicated sediment dissolution of $\mathrm{Mn}$ and $\mathrm{Fe}$ oxides. $\mathrm{Fe}^{2+}$ profiles generally highlighted a sharp increase (up to 520 and $544 \mu_{\mathrm{mol} \mathrm{I}}^{-1}$ at st D respectively in June and August) at the depth where $\mathrm{NO}_{3}^{-}$ disappeared, and a sharp decrease below $2-4 \mathrm{~cm}$ depth. On the contrary, $\mathrm{Mn}^{2+}$ profiles gradually increased and decreased with depth, concentrations never exceeding $18 \mu \mathrm{mol} \mathrm{I}^{-1}$. The profiles of $\mathrm{Fe}^{2+}$ were often more scattered than those of $\mathrm{Mn}^{2+}$. Concentrations of $\mathrm{Fe}^{2+}$ and $\mathrm{Mn}^{2+}$ were greatly influenced by the seasons especially at stations $B, X, D$ and $E$ where concentrations significantly increased from March to June. The lowest $\mathrm{Fe}^{2+}$ and $\mathrm{Mn}^{2+}$ concentrations were observed before the productive period in March (st A, B, C, D, E) or in December (st X and F).

\section{Phosphate and ammonium profiles}

Phosphate concentrations in the bottom waters ranged from about $0.5 \pm 0.3 \mu \mathrm{mol} \mathrm{I}^{-1}$ (st F) to $3.5 \pm 1.3$ $\left.\mu \mathrm{mol}\right|^{-1}$ (st A). Phosphate pore water profiles generally exhibited a weak concentration gradient at stations $A, B, C$ (inner estuary) and $F$ (outer estuary) particularly in the first ten centimeters where concentrations did not exceed $50 \mathrm{\mu mol}^{-1}$ (figure 3 ). However, isolated phosphate peaks may occur at around 8 or $12-14 \mathrm{~cm}$ according to the station or the location.

Conversely, phosphate profiles generally presented a sharp concentration gradient up to $8-10 \mathrm{~cm}$ depth at stations $X, E$ and even more markedly at station $D$ (concentrations up to 300-314 $\mu$ mol $~^{-1}$ in June and August). Further down, either the concentrations continued to increase slightly or they gently decreased. Phosphate profiles highlighted seasonal variations with the highest concentration peaks occurring in June or August according to the station and the location.

Ammonium profiles displayed the same behaviour as phosphate profiles but with about five time higher concentration levels (figure 3). The highest concentrations of $\mathrm{NH}_{4}^{+}$and $\mathrm{PO}_{4}^{3-}$ were always observed in the intermediate estuary.

\subsection{Solid fraction}

\section{Sediment characteristics (granulometry, porosity, Carbon and Nitrogen)}

Sediment characteristics of surficial sediments (in the top $3 \mathrm{~cm}$ ) are presented in table 3 .

A grain-size characterization was performed using the classes defined in Wentworth (1922) and Bellair and Pomerol (1977). Coefficients of variations were generally lower than $15 \%$, indicating a relatively stable grain-size nature of surficial sediments at each station over time. The relatively seasonal homogeneity in the sediment top layer was confirmed by using Friedman tests ( $n=24,95 \%$ confidence level) both for the lutite fraction $(<62.5 \mu \mathrm{m})$ and the sand fraction $(62.5-2000 \mu \mathrm{m})$. Station $\mathrm{F}$ presented the highest variabilities especially for the clay fractions $(<3.9 \mu \mathrm{m})$ which was relatively variable from one season to another (up to $\pm 20 \%$ ). According to the sedimentary characterization of Larsonneur (1977), the sediments were all silty sands. Nevertheless, the sediments at station A always presented the highest percentage of lutites (from $66 \pm 3 \%$ in March to $72 \pm 2 \%$ in December, June and August). 
The vertical distributions of porosity (not shown) highlighted a decrease from the surface to the deeper layers (around 2-6 cm) whatever the season, in particular at stations $B$ to $F$, and to a lesser extent at station A. The highest porosities (up to $85 \%$ ) always occurred at the upper estuary (station A) and the lowest (about 50-70 \%) either in the outer estuary (st F) or in the intermediate estuary (st X). A pattern of decreasing porosity in June in surficial sediments $(0-3 \mathrm{~cm})$ was observed at stations A, B, C, D and $\mathrm{E}$ (Friedman tests, $\mathrm{n}=24,95 \%$ confidence level).

The vertical distributions of organic carbon (not shown) displayed a decrease or almost constant concentrations with depth, except at station B in August which presented a surficial deficit. The highest concentrations (about $4000 \mu \mathrm{mol} \mathrm{g}{ }^{-1}$ ) always occurred at the upper estuary (st A) and the lowest (about $700 \mu \mathrm{mol} \mathrm{g}^{-1}$ ) either in the outer estuary (st F) or in the intermediate estuary (st C and X). A significant seasonal variability was observed at stations $B, C, D$ and $F$ with the highest concentrations in surficial sediments in June after the bloom (Friedman tests, $n=24,95 \%$ confidence level).

$\mathrm{C} / \mathrm{N}$ and $\mathrm{C} / \mathrm{P}$ molar ratios were quite variable further down the core, generally increasing with depth (respectively from about 9 to 12 and from about 250 to 550), and were considerably higher (table 3) than the Redfield ratio for marine organic matter of respectively 7:1 and 106:1 (Redfield, 1958).

\section{P forms}

The depth profiles of the seven sites showed differences both in the amount and proportion of the $P$ pools (figure $4 \mathrm{a}, 4 \mathrm{~b}$ and $4 \mathrm{c}$ ). By and large, all sites had maximum concentrations of total $\mathrm{P}$ in the surficial sediment (ranging from $12-22 \mu \mathrm{mol} \mathrm{g}^{-1}$ at st $F$ to $43-54 \mu \mathrm{mol} \mathrm{g}{ }^{-1}$ at st $A$ ). The concentrations declined gradually with depth except in August in the intermediate and outer estuaries (st C, D, E and F) where concentrations exhibited a marked decrease from the surface to $0.75 \mathrm{~cm}$ depth. This decrease in total $P$ was largely accounted for by a decrease in concentrations of Fe-P. Thus phosphate associated with iron hydroxides was a significant $P$ pool in the upper part of these sediments and could represent from about $20 \%$ (st X and F) to $57 \%$ (st A) of total P. The highest amount and proportion of total $P$ and Fe-P were always observed in the inner estuary (st $A$ ) and the lowest in the outer estuary (st F). A pattern of Fe-P decreasing in summer was observed at stations $\mathrm{C}$, $\mathrm{X}, \mathrm{D}$ and $\mathrm{F}$.

Exchangeable phosphate (Exch-P) as determined by the IDE method (Aminot and Andrieux, 1996) is included in the Fe-P fraction. Exch-P concentrations (figure 5) declined from the inner estuary (about 7 $\pm 1 \mu \mathrm{mol} \mathrm{g}^{-1}$ at st A) to the outer estuary (about $1.6 \pm 0.8 \mu \mathrm{mol} \mathrm{g}^{-1}$ at st F).

The concentration of Orga- $P$, calculated by subtracting inorganic $P$ from total $P$ should consequently be considered less precise than the concentrations of other phosphorus forms. The organic $\mathrm{P}$ content also generally decreased with depth (figure $4 a, 4 b, 4 c)$. The highest concentrations in surficial sediments (about 11-17 $\mu \mathrm{mol} \mathrm{g}^{-1}$ ) were always observed in the inner estuary (st $A$ ) and the lowest

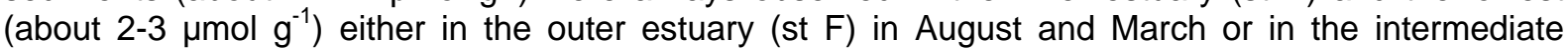
estuary (st $C$ and $X$ ) in December and June. The seasonal variation of Orga-P in the sediment top layer $(3 \mathrm{~cm})$ was not significantly different (Friedman, $\mathrm{n}=24,95 \%$ confidence level) except at station $\mathrm{F}$ where a significant increase was observed in June. Owing to the relatively wide concentration range, the Orga-P proportions in relation to total $\mathrm{P}$ were relatively variable (19-43\% on average), with the highest proportions encountered in August and June at stations $E$ and $F$.

In coastal sediments, phosphorus associated with $\mathrm{Ca}$ is present in solids of various types and origins. The distinction between two groups of Ca-associated $\mathrm{P}$ was made in this study according to Ruttenberg (1993): on one hand, detrital fluoroapatite of igneous and metamorphic origin, and on the other hand, other forms of Ca-P such as biogenic skeletal debris, $\mathrm{CaCO}_{3}^{-}$incorporated phosphate and carbonate fluoroapatite precipitated from interstitial solutions. Generally speaking, almost all detrital

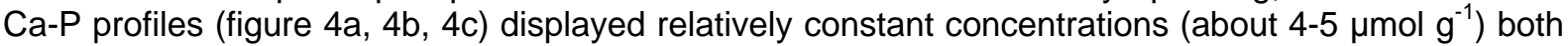
with depth and along the estuary. Only stations $E$ and $F$ exhibited a gradual decrease in concentrations in March (respectively from 5.3 to $3.4 \mu \mathrm{mol} \mathrm{g}^{-1}$ and from 5.6 to $3.1 \mu \mathrm{mol} \mathrm{g}{ }^{-1}$ ) and station A showed concentrations of up to $8.6 \mu \mathrm{mol} \mathrm{g}^{-1}(0.75 \mathrm{~cm}$ depth $)$ in August. In spite of relatively constant concentrations, Ca-P proportions in relation to total $\mathrm{P}$ increased with greater marine influence (from $12-15 \%$ to $50-60 \%$ of total $\mathrm{P}$ on average) due to the lower contribution of Fe-associated $\mathrm{P}$ and organic P. As with almost all profiles of Authigenic $P$ (figure $4 a, 4 b, 4 c$ ), concentrations showed a gradual decrease with depth or remained nearly constant. Only station $A$ in December and June displayed an increase in concentrations (respectively from about $9 \mu \mathrm{mol} \mathrm{g} \mathrm{g}^{-1}(14 \mathrm{~cm}$ depth) to $12 \mu \mathrm{mol} \mathrm{g}^{-1}$ (18.5 cm depth) and from $8.6 \mu \mathrm{mol} \mathrm{g}^{-1}\left(0.5 \mathrm{~cm}\right.$ depth) to $15 \mu \mathrm{mol} \mathrm{g}{ }^{-1}$ (3.5 cm depth). Concentrations in surficial sediments $(0.5 \mathrm{~cm})$ always declined from the inner estuary $\left(8-12 \mu \mathrm{mol} \mathrm{g}^{-1}\right.$ at st A) to the outer estuary (1.5-2 $\mu \mathrm{mol} \mathrm{g}{ }^{-1}$ at st F). Authigenic Ca-P accounted for about $20-23 \%$ of total $\mathrm{P}$ whatever the season, except at station $\mathrm{F}$ where it always represented about $14 \%$ of total $\mathrm{P}$. 


\subsection{Calculated phosphate diffusive fluxes}

Phosphate benthic fluxes (Fd) calculated from pore water gradients using Equation (1) (§ II.6) ranged from $-21.5 \mu \mathrm{mol} \mathrm{m} \mathrm{m}^{-2}$ to $410 \mu \mathrm{mol} \mathrm{m}^{-2} \mathrm{~d}^{-1}$ over the whole estuary (figures 7 and 8 ). Very low phosphate fluxes $\left(<6 \mu \mathrm{mol} \mathrm{m} \mathrm{m}^{-2} \mathrm{~d}^{-1}\right)$ or even sediment uptakes were observed in the intermediate estuary both in May 2003 and March 2005 prior to maximum Alexandrium minutum cell densities (figures 7, 8 and table 4). A significant release (from about 50 to $410 \mu \mathrm{mol} \mathrm{m}^{-2} \mathrm{~d}^{-1}$ ) occurred during and after maximum cell concentrations reported in the intermediate estuary (figures 7,8 and table 4).

\section{Discussion}

\subsection{Diagenetic processes in the sediments of the Penzé estuary}

$\mathrm{NH}_{4}^{+}$and $\mathrm{PO}_{4}^{3-}$ pore water profiles in the present study indicate that there is nutrient regeneration. Such regeneration is driven mainly by organic matter decomposition which occurs more intensively in the intermediate and outer estuaries (st X, D and E) in June and August and even in December (st D and E). However, at some stations, nutrient profiles exhibit a vertical shape, especially in winter, reflecting low inputs of biodegradable organic matter. Several other parameters -both in the pore water and in the solid phase- confirm the occurrence of mineralization in spring in sediments of the Penzé estuary. First, $\mathrm{O}_{2}$, and subsequently $\mathrm{NO}_{3}^{-}$are consumed, and their penetration depths decrease from March to June after the bloom. Also, $\mathrm{Fe}^{2+}$ and $\mathrm{Mn}^{2+}$ concentration levels generally increase from March to June, as Fe-oxides and Mn-oxides are used as electron acceptors (figure 2 ). $\mathrm{Fe}^{2+}$ generally appears at depths where nitrate concentrations are below the detection limit. This means that nitrate could be the primary oxidant for $\mathrm{Fe}^{2+}$. Despite low concentration levels, $\mathrm{Mn}^{2+}$ appears below the detection limit of the bottom of the oxygen-bearing layer suggesting that $\mathrm{O}_{2}$ is the primary oxidant of $\mathrm{Mn}^{2+}$, which diffuses upwards. This was also observed in the muddy sediments of the Bay of Biscay (Hyacinthe et al., 2001). With regard to solid phase, our data generally highlight the decrease in Orga$\mathrm{P}$ and Orga-C concentrations with depth (figures not shown). This pattern is usual in depositional environments where the burial and mineralization of organic matter occur gradually in the deeper sediment layers (Morris and Bowden, 1986; Paludan and Morris, 1999). However, the distributions in sedimentary organic matter may sometimes be homogeneous which often points to a more intense bioturbation. Finally, the $\mathrm{C} / \mathrm{N}$ and $\mathrm{C} / \mathrm{P}$ ratios, higher than the Redfield ratios for phytoplankton, may reflect more rapid mineralization of $\mathrm{N}$ and $\mathrm{P}$ relative to $\mathrm{C}$. Nevertheless, this difference with Redfield ratios may also reflect the presence of organic matter derived from more $\mathrm{C}$-rich plant detritus. Currently, organic carbon contents in cultivated soils can reach $15000 \mu \mathrm{mol} \mathrm{g}{ }^{-1}$ in the finest particles (Calvet, 2005).

Phosphorus behaves in a particular manner as its presence in interstitial waters is also controlled by the redox cycle of Fe which greatly affects its geochemistry after burial. In fact, Fe-oxides present in the oxic layer of the sediment can act as a trap for upwardly diffusing phosphate (Krom and Berner, 1980; Sundby et al., 1992; Slomp et al., 1996a). The Fe-P profiles in the Penzé estuary (figure 4a, 4b and 4c) show evidence of phosphorus enrichment due to Fe re-oxidation in sediment surficial layers. This is in agreement with observations made in other estuarine systems (Jensen and Thamdrup, 1993; Paludan and Morris, 1999; Coelho et al., 2004). Fe-P decreases with depth and reaches stable values in sediments of the Penzé estuary. This is attributed to the reduction of Fe-oxides in the anoxic sediment layer, liberating the associated phosphate, in addition to the phosphate released during organic matter decomposition (Krom and Berner, 1980). Likewise, anoxia caused by the mineralization of organic matter following the sedimentation of the spring bloom, could explain the surficial Fe-P decrease in summer in the intermediate and outer estuaries. Furthermore, the release of $\mathrm{PO}_{4}^{3-}$ from Fe-P may contribute to the decrease of $\mathrm{NH}_{4}^{+} / \mathrm{PO}_{4}^{3-}$ ratios in surficial pore waters from March (about 8 to 18 ) to June (about 2 to 6 ) in this area.

At all stations Fe-P concentrations do not completely fall to zero even when there is no more $\mathrm{NO}_{3}^{-}$and thus no more $\mathrm{O}_{2}$. Ruttenberg and Berner (1993), Anschutz et al. (1999) and Slomp et al. (1996) have also observed a clear persistence of Fe-P inside the reduced zone and concluded that Fe-oxides 
could provide a temporary sink for $\mathrm{P}$ respectively in continental margin environments, in modern sediments of the Bay of Biscay and in the North sea sediments. This could imply that some Fe-oxide forms may well be protected from reduction, due to reduced iron compound coatings (Postma, 1993) and to the presence of surface bound P, Si and organics (Slomp et al., 1996a). Fisher et al. (1982) have also mentioned the possibility of the precipitation of reduced minerals such as vivianite in an increasingly reduced environment. Moreover, Williams (1980) has shown that vivianite was extracted using dithionite.

Another type of diagenetic removal regarding phosphate is the formation of authigenic phases such as carbonate fluoroapatite (CFA) from phosphate released during the mineralization processes or the dissolution of iron oxides (Ruttenberg, 1990; Ruttenberg and Berner, 1993). The increase in authigenic $P$ concentrations in relation to depth shows that CFA could form in the sediments of station A as already described in coastal marine sediments (Slomp et al., 1996a). However, the relatively constant profiles observed at the other stations do not necessarily preclude the precipitation of CFA since this could be masked by bioturbation or could occur at the sediment-water interface (Van der Zee et al., 2002).

Conversely, detrital Ca-P seems to be a more inert phosphorus forms as shown by smooth distributions whatever the sediment characteristics (i. e., percentage of fine particles). Such pattern have already been reported in coastal environments (Andrieux-Loyer and Aminot, 2001; Morse and Cook, 1978) and suggests that surface effects are of minor importance and that calcium phosphate is mainly present within the matrix of the sediment minerals. This is illustrated by the absence of correlation $\left(r^{2}<0.2\right)$ between detrital Ca-P and the fine fraction $(<63 \mu \mathrm{m})$ and between detrital Ca-P and $\mathrm{Ca}$ concentrations $\left(r^{2}<0.1\right)$.

\subsection{Sedimentary bioavailable Phosphorus}

This study aims to improve our understanding of Alexandrium minutum events. Thus, the notion of bioavailability must be taken into account. Bioavailability has been assessed by bioassays (de Jonge et al., 1993). However, our knowledge of phosphorus forms provides us with maximum levels of potentially bioavailable phosphorus. Authigenic and biogenic Ca-P in sediments are almost insoluble under the physico-chemical conditions of estuarine waters and cannot play a role in interstitial or overlying water enrichment (Williams et al., 1980; Ruttenberg, 1992; Berner et al., 1993; Jensen and Thamdrup, 1993). In the anoxic sediments of the Penzé estuary, phosphate may be released both from the reduction of Fe oxide-bound phosphate (Fe-P) and from the mineralization of organic matter (Orga-P).

The inner part of the estuary (figure 4a), with the greatest freshwater influence, always represented the largest sinks of potentially bioavailable $\mathrm{P}$ (Fe-P which includes Exch-P and Orga-P). This area is characterized by low current velocities and long residence times which allow a greater sedimentation of fine particles (Bassoulet, pers. comm.), rich in organic matter and in Fe-oxides. This is shown by the significant linear relationships between Orga-C or $\mathrm{Fe}_{2} \mathrm{O}_{3}$ and the $<63 \mu \mathrm{m}$ fraction (respectively $r^{2}=$ $0.66 ; P<0.01$ and $r^{2}=0.67 ; P<0.01 ; n=215$ ). Conversely, in the outer area of the estuary, ironbound $P$ (figure $4 \mathrm{c}$ ) and exchangeable phosphate in surficial sediment (figure 5) were lower. This could be explained by two processes. First, the increase in $\mathrm{pH}$ along with higher salinity may produce the release of adsorbed $\mathrm{P}$ from the iron complexes due to competition with $\mathrm{OH}$ ions. Also, Fe oxides may be consumed during formation of pyrite $\left(\mathrm{FeS}_{2}\right)$, which can sequester a large fraction of sediment Fe which becomes unavailable for phosphate (Krom and Berner, 1980; Paludan and Morris, 1999; Coelho et al., 2004). The importance of this Fe-S interaction would be greatest in marine sediments with significant sulphate reduction.

In addition, the particulate Fe/P ratios in oxic surficial layers (figure 6) suggest that the inner and intermediate areas are the most important in terms of $\mathrm{P}$ liberation. Particulate Fe/ $\mathrm{P}$ ratios are considered to be indicators of free sorption sites for phosphate ions on iron-oxyhydroxides (Coelho et al., 2004; Paludan and Jensen, 1995). Low Fe/P ratios $(<8)$ in the present study suggest less capacity to adsorb phosphate or even the saturation of sorption sites, resulting in phosphate fluxes to the overlying water, especially in the intermediate estuary. This could promote the occurrence of Alexandrium minutum and eutrophic conditions, especially in the inner and intermediate estuaries, despite management efforts to reduce phosphate loading from external sources.

Particulate Fe/P ratios generally increase with depth as the sediment become anoxic. This phenomenon is particularly marked in the intermediate estuary in March and June (from 4.5 to 18 at station D and from 5.3 to 11 at st $X$ in December). According to Stumm (1992), the reductiondissolution of Fe-oxides at the surface of minerals and clays proceeds in several steps. The last one, i.e., detachment of $\mathrm{Fe}(\mathrm{II})$ ions from the matrix is slow. When Fe-oxides- $\mathrm{PO}_{4}$ complexes are destroyed, 
$\mathrm{PO}_{4}$ is liberated while $\mathrm{Fe}(\mathrm{II})$ remains attached to the solid for a long time. Higher Fe/P ratios in deeper anoxic sediment layers especially in the intermediate estuary support the hypothesis that slow detachment of $\mathrm{Fe}(\mathrm{II})$ ions from the solid matrix is the rate determining process.

Bioavailable $P$ concentrations were integrated with depth to obtain the total exchangeable $\mathrm{P}$ mass (Fe$\mathrm{P}+$ Orga- $\mathrm{P}$ ) on a sedimentary layer of $3 \mathrm{~cm}$. This depth was chosen as it is likely to be subjected to bioturbation or resuspension (Bassoullet, pers. comm.). In the inner part of the estuary $\left(\sim 0.5 \mathrm{~km}^{2}\right)$, and taking into account the average bioavailable phosphorus concentrations $\left(15 \mu \mathrm{mol} \mathrm{g}^{-1}\right)$, there is a potentially bioavailable phosphorus pool of about 35 tons $\mathrm{P}$. In the intermediate and outer parts of the estuary $\left(\sim 1,5 \mathrm{~km}^{2}\right)$, the mean concentration of bioavailable phosphorus is $3 \mu \mathrm{mol} \mathrm{g}{ }^{-1}$, which corresponds to a stock of 23 tons $P$. This total load of potentially bioavailable phosphorus which corresponds to about eight years of external loadings $\left(7\right.$ ton year $\left.^{-1}\right)$, could be released from sediments in the event of favourable environmental conditions (notably if oxygen conditions in the near bottom waters deteriorated or if the oxic sediment layer was destroyed due to resuspension of sediments by flood, tidal currents or dredging).

\subsection{Phosphate diffusive fluxes: benthic versus river fluxes}

The present study highlight the heterogeneity of phosphate fluxes along the estuary, particularly in June and August. This could partly be attributed to the fact that the Penzé estuary, like many estuaries, are highly dynamic environments (Sanders et al., 1997), in which sediments are subjected to substantial resuspension events. In addition, the present investigation shows the significant increase of phosphate diffusive fluxes from March to June especially in the intermediate estuary. Seasonality in benthic nutrient fluxes could be accounted for by an effect of temperature on both diffusion and metabolic activity of benthic organism (Clavero et al., 2000). Another possible explanation for the flux enhancements could be that the sediment liberate phosphate in response to the decrease in concentrations in the water column due to an uptake by the phytoplanktonic community. The role of sediments in buffering phosphate concentrations has been described in other coastal environments. For example, Van Raaphorst et al. (1988) showed in the Dutch Wadden Zee that phosphate is removed from the water column to the sediment in autumn and winter when phosphate concentrations are high, and is released in spring and summer when phosphate concentration are lower due to the phytoplankton uptake.

These flux data can be used to give a rough estimate of the role played by the sediments in the nutrient budget of the estuary. Taking into account the studied area (about $2 \mathrm{~km}^{2}$ ), phosphate inputs from sediments ranged from about 2-4 $\mathrm{kg} \mathrm{d}^{-1}$ in June-July 2003 , which represented $10-20 \%$ of the external discharges (about $20 \mathrm{~kg} \mathrm{~d}^{-1}$ ). In August 2004 and in June 2005, in the intermediate estuary (from Eon Bridge to Corde Bridge: about $0.6 \mathrm{~km}^{2}$ ), where the highest cell densities were measured, the inputs from sediments ranged from 1 to $7 \mathrm{~kg} \mathrm{~d}^{-1}$ which represented about 7 to $50 \%$ of the river loadings (about $\left.15 \mathrm{~kg} \mathrm{~d}^{-1}\right)$. By considering an average flux $\left(75 \mu \mathrm{mol} \mathrm{m}{ }^{-2} \mathrm{~d}^{-1}\right)$ on the whole estuary $\left(2 \mathrm{~km}^{2}\right)$, the contributions of the sediments were of the order of $5 \mathrm{~kg} \mathrm{~d}^{-1}$ both in June and August corresponding to about $30 \%$ of the external supplies. Alexandrium minutum requirements in nitrogen to form a bloom are supplied by the Penzé River, whose nitrogen levels are excessive (about $800 \mathrm{mmol}^{-1}$; N/P superior to 100). Concerning phosphate, the situation is more complex. River inputs in phosphate are not sufficient to maintain the Alexandrium minutum bloom (Maguer et al., 2004). The sediment could then supply the complementary phosphate required by Alexandrium minutum. However, the phosphorus supplies both from the river and the sediment are not sufficient to promote a bloom (Chapelle, pers. comm.). But it is necessary to bear in mind that diffusive fluxes have to be represented as a minimal threshold of the real contributions made by the sediment (Barbanti et al., 1992). In fact, phosphate regenerated at the sediment-water interface, which directly diffuses back to the bottom water, like phosphate transport induced by bioturbation is not taken into account in calculations (Schenau and De Lange, 2001). To illustrate this idea, wide-scale divergences between diffusive fluxes and in-situ fluxes (benthic chamber) have already been reported and attributed either to bioturbation provoked by certain species of the benthic macrofauna (Callender, 1982) or to the release of gas bubbles which enhances transport during summer (Martens and Klump, 1980). However, in-situ measurements of nutrient fluxes in highly dynamic environments such as estuaries, can also be dubious as benthic chamber experiments isolate the sediments from the overlying hydrodynamics (Oldham and Lavery, 1999).

In addition, regeneration by mineralization and desorption of the particulate phosphorus -not taken into account in this study- could also be another source of phosphorus for Alexandrium minutum growth. As an example, studies of speciation in the Seine estuary showed that heavy loads of particles expelled from the estuary during spring floods, contain $50 \%$ of bioavailable P and may therefore 
significantly contribute to the enrichment of the Bay of Seine when phytoplankton is actively growing (Aminot et al., 1993).

\section{Conclusion}

Our findings highlight the substantial sediment buffering capacity of the Penzé estuary system. The inner and intermediate areas are the most important in terms of $P$ liberation, as suggested by the lower Fe/P ratio. Pools of bioavailable $\mathrm{P}$ in the surficial sediment are about 8 times higher than the annual net river input of $\mathrm{P}\left(7\right.$ ton year $\left.{ }^{-1}\right)$. Pore water and flux results exhibit the spatio-temporal heterogeneity of phosphate supplies from the sediments. The highest phosphate supplies occurring in June and August in the intermediate estuary may represent up to $50 \%$ of river loadings. In spite of the seasonal variability of diffusive fluxes along the estuary, these results further suggest that phosphate pulses coincide with occurrences of Alexandrium minutum reported in June. Management measures to reduce nutrient inputs into estuarine systems should therefore consider that $\mathrm{P}$ availability may persist as a result of sediment supply, even after reducing the external point sources.

This study also confirms the need for more attention to be given to speciation and nutrient flux evaluations when investigating of the biogeochemical behaviour of nutrients. Further research should also be carried out into the nature, the behaviour and the liberation kinetics of the bioavailable phosphorus in coastal environments. Our results can also play a role in improving dynamic models of primary production by considering the internal sedimentary source of nutrients in order to produce a tool for management studies.

\section{Acknowledgements}

This research has been partially funded by the Improving Coastal and Recreational Waters project (ICREW). We wish to thank Philippe Cann, Anne Daniel-Scuiller, Marie-Madeleine Danielou and Erwan Le Gall for their helpful collaboration during the sampling surveys. Thanks to an anonymous reviewer, Daniel Delmas, Jean-François Guillaud and Claire Labry who provided numerous helpful comments. Thanks to Anne-Laure Le Velly and Juliette Fauchot for English corrections. We should also especially like to thank Alain Aminot for his support and guidance over the past years.

\section{References}

Aller RC, Yingst JY (1980) Relationships between microbial distributions and the anaerobic decomposition of organic matter in surface sediments of Long Island Sound, USA. Marine Biology 56(1): 29-42.

Aminot A, Andrieux $F$ (1996) Concept and determination of exchangeable phosphate in aquatic sediments. Water Research 30(11): 2805-2811.

Aminot A, Guillaud JF, Andrieux F (1993) Spéciation du phosphore et apports en baie de Seine orientale. Oceanologica Acta 16(5-6): 617-623.

Aminot A, Kérouel R (2007) Dosage automatique des nutriments dans les eaux marines: méthodes en flux continu. Ed. Ifremer, Méthodes d'analyse en milieu marin, $188 \mathrm{p}$.

Andrieux F, Aminot A (1997) A two-year survey of phosphorus speciation in the sediments of the Bay of Seine (France). Continental Shelf Research 17(10): 1229-1245.

Andrieux-Loyer F, Aminot A (2001) Phosphorus forms related to sediment grain size and geochemical characteristics in French Coastal Areas. Estuarine Coastal and Shelf Science 52: 617-629.

Anonymous (2004) 2003 Activity report, IFREMER Publishing (May 2004, R. INT. DEL/EC/04-03), 105 p.

Anschutz P, Hyacinthe C, Carbonel P, Jouanneau JM, Jorissen F (1999) La distribution du phosphore inorganique dans les sédiments modernes du Golfe de Gascogne. Académie des Sciences 328: 765771.

Aspila KI, Agemian H, Chau AS (1976) A semi-automated method for the determination of inorganic, organic and total phosphate in sediments. Analyst 101: 187-197. 
Avilés A, Niell FX (2005) Pattern of phosphorus forms in a Mediterranean shallow estuary : Effects of flooding events. Estuarine Coastal and Shelf Science 64: 786-794.

Bally G, Andrieux-Loyer F, Kérouel R, Verney R, Youenou A, Philippon X (2008) Do macrotidal hydrodynamic conditions influence nutrient release and pore water chemistry ? In preparation.

Barbanti A, Ceccherelli VU, Frascari F, Reggiani G, Rosso G (1992) Nutrient regeneration processes in bottom sediments in a Po delta lagoon (Italy) and the role of bioturbation in determining the fluxes at the sediment-water interface. Hydrobiologia 228: 1-21.

Beller P, Pomerol P (1977) Eléments de Géologie. Armand Colin, Paris, 528 p.

Berner RA (1980) Early Diagenesis: A theorical Approach. Princeton Univ. Press, Princeton, NJ, p. 914.

Berner RA, Ruttenberg KC, Rao JiL (1993) The nature of phosphorus burial in modern marine sediments. In: Interactions of C,N,P and S Biogeochemical Cycles and Global Changes, R. Wollast, F.T. Mackenzie, L. Chou, editors, Spriger-Verlag, NATO ASI Series I: Global Environmental Change, Vol. 4.

Boudreau BP (1996) The diffusive tortuosity of fine-grained unlithified sediments. Geochimica Cosmochimica Acta 60: 3139-3142.

Callender E, Hammond DE (1982) Nutrient exchanges acroos the sediment-water interface in the PotomacRiver estuary. Estuarine Coastal and Shelf Science 15(4): 395-415.

Calvet R (2005) Le Sol: propriétés et fonctions, tome 1, constitution et structure, phénomènes aux interfaces. (France Agricols, Ed), DUNOD Publishing, p 164.

Cauwet G (1975) Optimisation d'une technique de dosage du carbone organique des sediments. Chemical Geology 16: 59-63.

Clavero V, Izquierdo JJ, Fernández JA, and Niell FX (1999b) Influence of bacterial density on the exchange of phosphate between sediment and overlying water. Hydrobiologia 392(1): 55-63.

Clavero V, Izquierdo JJ, Fernández JA, and Niell FX (2000) Seasonal fluxes of phosphate and ammonium across the sediment-water interface in a shallow small estuary (Palmones River, southern Spain). Marine Ecology Progress series 198: 51-60.

Coelho JP, Flindt MR, Jensen HS, Lillebø AI, Pardal MA (2004) Phosphorus speciation and availability in intertidal sediments of a temperate estuary: relation to eutophication and annual $P$ fluxes. Estuarine Coastal and Shelf Science 61:583-590.

De Jonge VN, Engelkes MM, Bakker JF (1993) Bio-availability of phosphorus in sediments of the western Dutch Wadden Sea. Hydrobiologia 253: 151-163.

ECOFLUX 2007. Qualité des eaux de treize rivières du Finistère. IUEM-Réseau Ecoflux, Place Nicolas Copernic, 29280 Plouzané.

Ehrenhauss SU, Witte U, Janssen F and Huettel M (2004) Decomposition of diatoms and nutrients dynamics in permeable North Sea sediments. Continental Shelf Research 24: 721-737.

Erard-Le Denn E (1997). Alexandrium minutum. In: Efflorescences Toxiques des Eaux Côtières Françaises : Ecologie, Ecophysiologie, Toxicologie (Berland B. and Lassus P. eds), IFREMER/Brest Publishing, p 53-65.

Fisher TR, Carlson PR and Barber RT (1982) Sediment nutrient regeneration in three North Carolina estuaries. Estuarine Coastal and Shelf Science 14(1): 101-116.

Froelich PN (1988) Kinetic control of dissolved phosphate in natural rivers and estuaries: A primer on the phosphate buffer mechanism. Limnology and Oceanography 33: 649-668.

Gallioz, C (2004) Etude préliminaire: évaluation du rôle du phosphore sédimentaire dans la dynamique d'apparition des blooms d'Alexandrium minutum en estuaire de Penzé, 29 p.

http://www.ifremer.fr/delec/communication/rapports/rapport2.htm

Hyacinthe C, Anschutz P, Carbonel P, Jouanneau JM, Jorissen FJ (2001) Early diagenetic processes in the muddy sediments of the Bay of Biscay. Marine Geology 177: 111-128.

Jensen HS, Thamdrup Bo (1993) Iron-bound phosphorus in marine sediments as measured by bicarbonate-dithionite extraction. Hydrobiologia 253: 47-59.

Kérouel R, Aminot A (1997) Fluorimetric determination of ammonia in sea and estuarine waters by direct segmented flow analysis. Marine Chemistry 57: 265-275.

Krom MD, Berner RA (1980) The diffusion coefficients of sulphate, ammonium, and phosphate ions in anoxic marine sediments. Limnology and Oceanography 25: 327-337.

Labry C, Erard-Le Denn E, Chapelle A, Fauchot J, Youenou A, Crassous M.P, Le Grand J, Lorgeoux $B$ (in press) Competition for phosphorus between two dinoflagellates : a toxic Alexandrium minutum and a non-toxic Heterocapsa triquetra. Journal of Experimental Marine Biology and Ecology.

Larsonneur C (1971) Manche Centrale et Baie de Seine: géologie du substratum et des dépôts meubles. Thèse d'état de l'Université de Caen, $n^{\circ}$ A.0.5404, 387 p. 
Li YH, Gregory S (1974) Diffusion of ions in sea water and in deep-sea sediment. Geochimica Cosmochimica Acta 33: 703-714.

Maguer JF, Wafar M, Madec C, Morin P, Erard-Le Denn E (2004) Nitrogen and phosphorus requirements of an Alexandrium minutum bloom in the Penzé Estuary, France. Limnology and Oceanography 49(4): 1108-1114.

Manheim FT (1970) The diffusion of ions in unconsolidated sediments. Earth Planet Sci Lett 9: 307309.

Martens CS, Klump JV (1980) Biogeochemical cycling in an organic-rich coastal marine basine. 1. Methane sediment-water exchange processes. Geochimica Cosmochimica Acta, 44(3), 471-490

Morris JT, Bowden WB (1986) A mechanistic, numerical model of sedimentation, mineralization, and decomposition for March sediments. Soil Sci. Soc. Am. J. 50: 96-105.

Morse JW, Cook N (1978) The distribution and forms of phosphorus in North Atlantic Ocean deep-sea and continental slope sediments. Limnology and Oceanography, 23: 825-830.

Mudroch A, Azcue JM (1995) Manual of aquatic sediment sampling. Lewis publishers. CRC press inc. 252p.

Oldham CE, Lavery PS (1999) Porewater nutrient fluxes in a shallow fetch-limited estuary. Marine Ecology Progress Series 183: 39-47.

Paludan C, Jensen HS (1995) Sequential extraction of phosphorus in freshwater wetland and lake sediment, significance of humic acids. Wetlands 15:365-373.

Paludan C, Morris JT (1999) Distribution and speciation of phosphorus along a salinity gradient in intertidal March sediments. Biogeochemistry 45: 197-221.

Postma D (1993) The reactivity of iron oxides in sediments: A kinetic approach. Geochimica and Cosmochimica Acta 57(21-22): 5027-5034.

Psenner R, Boström B, Dinka M, Petterson K, Pucsko R, Sager M (1988) Fractionation of phosphorus in suspended matter and sediment. Arch. Hydrobiol. Beih. Ergebn. Limnol. 30:98-103.

Redfield AC (1958) The biological control of chemical factors in the environment. American Journal of Science 46: 205-222.

Resing JA, Mottl M J (1992) Determination of Manganese in Seawater Using Flow Injection Analysis with On-Line Preconcentration and Spectrophotometric Detection. Anal. Chem. 64: 2682-2687.

Ruttenberg KC (1990) Diagenesis and burial of phosphorus in marine sediments: Implications for the marine phosphorus budget. Ph. D. thesis, Yale Univ., $375 \mathrm{p}$.

Ruttenberg KC, Turnewitsch R, Witte U, Graf G (1992) Development of a sequential extraction method for different forms of phosphorus in marine sediments. Limnology and Oceanography 37(7): 14601482.

Ruttenberg KC, Berner RA (1993) Authigenic apatite formation and burial in sediments from nonupwelling, continental margin environments. Geochimica Cosmochimica Acta 57: 991-1007.

Sarradin PM, Le Bris N, Le Gall C, Rodier P (2005) Fe analysis by the ferrozine method: Adaptation to FIA towards in situ analysis in hydrothermal environment. Talanta 66: 1131-1138.

Schenau SJ, De Lange GJ (2001) Phosphorus regeneration vs. burial in sediments of the Arabian Sea. Marine Chemistry 75:201-217.

Schlungbaum G, Nausch G (1990) Phosphate sorption equilibrium at sediment-water interfacesConsequences for the rehabilitation of waters. In:.Michaelis (ed) Coastal and Estuarine Studies, Estuarine Water Quality Management, Monitoring, Modelling and Research. Springer-Verlag, Berlin.

Slomp CP, Epping EHG,. Helder W, Van Raaphorst W (1996a) A key role for iron-bound phosphorus in authigenic apatite formation in North Atlantic continental platform sediments. Journal of Marine Research 54: 1179-1205.

Smil V (2000) Phosphorus in the environment: Natural flows and human interferences. Annual Review of Energy and the Environment. 25:53-88.

Stumm W (1992) Chemistry of the Solide-Water Interface. In Processes at the mineral-water and particulate interface in natural systems. Wiley-Interscience Publication, New York, 428 pp.

Sundby B, Gobeil N, Silverberg N, Mucci A (1992) The phosphorus cycle in coastal marine sediments. Limnology and Oceanography 37: 1129-1145.

Sundby B (2006) Transient state diagenesis in continental margin muds. Marine Chemistry 102(1-2): 2-12.

Van der Zee C, Slomp CP, Van Raaphorst W (2002) Authigenic P formation and reactive P burial in sediments of the Nazaré canyon on the Iberian margin (NE Atlantic). Marine Geology 185: 379-392.

Van-Raaphorst W, Ruardij P, Brinkman AG (1988) The assessment of benthic phosphorus regeneration in an estuarine ecosystem model. Netherland Journal of Sea Research: 22(1): 23-36.

Waeles M (2005) Seasonal variations of cadmium speciation in the Penzé estuary, NW France. Estuarine Coastal and Shelf Science 62(1-2): 313-323. 
Wenthworth CK (1922) Grade and class terms for clastic sediments. Journal of Geology 30: 327-392. Williams JDH, Mayer T, Nriagu JO (1980) Extractability of phosphorus from phosphate minerals common in soils and sediments. Soil Sci. Soc. Am. J. 44:462-465. 
Table 1

Summary of overlying physical-chemical water properties (river discharge, water depth, salinity, temperature) in 2003 in the intermediate estuary (st X) and in 2004-2005 along the estuary.

\begin{tabular}{llllllll}
\hline $\begin{array}{l}\text { Sampling } \\
\text { date }\end{array}$ & 27.04 .2003 & 11.06 .2003 & 9.07 .2003 & 24.08 .2004 & 3.12 .2004 & 4.03 .2005 & 13.06 .04 \\
\hline $\begin{array}{l}\text { Penze } \\
\text { outflow } \\
\left(\mathrm{m}^{3} \mathrm{~s}^{-1}\right)\end{array}$ & 1.26 & 0.67 & 0.46 & 0.96 & 1.66 & 3.53 & 0.92 \\
$\begin{array}{l}\text { Water depth } \\
(\mathrm{m})\end{array}$ & 0.8 & 0.7 & 0.7 & $0.2-1$ & $0.2-1$ & $0.4-1.2$ & $0.3-1$ \\
$\begin{array}{l}\text { Temperature } \\
\left({ }^{\circ} \mathrm{C}\right)\end{array}$ & 15.0 & 20.0 & 23.7 & $17-17.8$ & $6.7-8.5$ & $4.7-6$ & $17.9-18.3$ \\
Salinity & $\begin{array}{l}(1)^{\star} 30.2 \\
(2)^{*} 30.2\end{array}$ & 30 & $(1)^{*} 29.1$ & $11.6-34.3$ & $4.2-34.1$ & $0-34.1$ & $0-34.4$ \\
$*(1)$ : core 1; (2): core 2 & & $(2)^{*} 29.7$ & & & &
\end{tabular}

Table 2

Sequential extraction method for P in sediments (after Psenner et al., 1980; Ruttenberg, 1990; Aspila, 1992)

\begin{tabular}{|c|c|c|}
\hline Step & Extractant and Protocol & Phase extracted \\
\hline $\begin{array}{l}\text { I) Adsorbed + iron- } \\
\text { bound }\end{array}$ & $0.1 \mathrm{~mol} \mathrm{I}^{-1}$ Dithionite-Bicarbonate (DB) , $8 \mathrm{~h}, 20^{\circ} \mathrm{C}$ & $\begin{array}{l}\text { Exchangeable or loosely sorbed } \\
\mathrm{P}+\text { easily reducible Fe-bound } \mathrm{P}\end{array}$ \\
\hline II) Authigenic & $\begin{array}{l}\text { a) } 1 \mathrm{~mol} \mathrm{I}^{-1} \mathrm{Na} \text {-acetate buffer } \\
\left(\mathrm{pH}=4,6 \mathrm{~h}, 20^{\circ} \mathrm{C}\right) \\
\text { b) washing with } 1 \mathrm{~mol}{ }^{-1} \mathrm{MgCl}_{2},(\mathrm{pH}=8,0.5 \mathrm{~h} \text {, } \\
20^{\circ} \mathrm{C} \text { ) }\end{array}$ & $\begin{array}{l}\text { Carbonate fluoroapatite (CFA) }+ \\
\text { biogenic hydroxyapatite }+ \\
\mathrm{CaCO}_{3} \text {-bound } \mathrm{P}\end{array}$ \\
\hline III) Det & $1 \mathrm{~mol} \mathrm{I}^{-1} \mathrm{HCl}$, overnight & Detri \\
\hline IV) Organic & Ash at $550^{\circ} \mathrm{C}$, then $1 \mathrm{~mol} \mathrm{I}^{-1} \mathrm{HCl}$ treatment overnight & Organic $\mathrm{P}$ \\
\hline
\end{tabular}


Table 3

Surficial sediment (in the top $3 \mathrm{~cm}$ ) characteristics at each study site over the study period.

\begin{tabular}{|c|c|c|c|c|c|c|c|}
\hline Station & $A$ & $B$ & C & $\mathrm{X}$ & $\mathrm{D}$ & $E$ & $\mathrm{~F}$ \\
\hline $\mathrm{n}$ & 24 & 24 & 24 & 12 & 24 & 24 & 24 \\
\hline Granulometry & 72 & 57 & 46 & 45 & 51 & 56 & 50 \\
\hline Silt + Clay (\%) & (4) & (3) & (5) & (6) & (4) & (5) & (8) \\
\hline Porosity (\%) & $\begin{array}{l}80 \\
(5)\end{array}$ & $\begin{array}{l}69 \\
(6)\end{array}$ & $\begin{array}{l}60 \\
(8)\end{array}$ & $\begin{array}{l}58 \\
(8)\end{array}$ & $\begin{array}{l}61 \\
(8)\end{array}$ & $\begin{array}{l}62 \\
(10)\end{array}$ & $\begin{array}{l}58 \\
(8)\end{array}$ \\
\hline$\left.C(\mu \mathrm{mol} \mathrm{g})^{-1}\right)$ & $\begin{array}{l}4056 \\
(366)\end{array}$ & $\begin{array}{l}2413 \\
(937)\end{array}$ & $\begin{array}{l}1170 \\
(828)\end{array}$ & $\begin{array}{l}1161 \\
(919)\end{array}$ & $\begin{array}{l}1382 \\
(244)\end{array}$ & $\begin{array}{l}1417 \\
\text { (316) }\end{array}$ & $\begin{array}{l}731 \\
(353)\end{array}$ \\
\hline $\mathrm{N}\left(\mu \mathrm{mol} \mathrm{g} \mathrm{g}^{-1}\right)$ & $\begin{array}{l}327 \\
(141)\end{array}$ & $\begin{array}{l}186 \\
(104)\end{array}$ & $\begin{array}{l}110 \\
(66)\end{array}$ & $\begin{array}{l}113 \\
(87)\end{array}$ & $\begin{array}{l}137 \\
(26)\end{array}$ & $\begin{array}{l}150 \\
(47)\end{array}$ & $\begin{array}{l}87 \\
(48)\end{array}$ \\
\hline Orga-P $\left(\mu \mathrm{mol} \mathrm{g}{ }^{-1}\right)$ & $\begin{array}{l}12 \\
\text { (2) }\end{array}$ & $\begin{array}{l}5.5 \\
(0.2)\end{array}$ & $\begin{array}{l}3.3 \\
(1.3)\end{array}$ & $\begin{array}{l}2.7 \\
(0.5)\end{array}$ & $\begin{array}{l}4.2 \\
(1.2)\end{array}$ & $\begin{array}{l}4.8 \\
(1.8)\end{array}$ & $\begin{array}{l}3.1 \\
(2)\end{array}$ \\
\hline $\mathrm{C} / \mathrm{N}$ & $\begin{array}{l}11 \\
(1)\end{array}$ & $\begin{array}{l}11 \\
(1)\end{array}$ & $\begin{array}{l}10 \\
(1)\end{array}$ & $\begin{array}{l}10 \\
(1)\end{array}$ & $\begin{array}{l}10 \\
(1)\end{array}$ & $\begin{array}{l}10 \\
(1)\end{array}$ & $\begin{array}{l}9 \\
(1)\end{array}$ \\
\hline $\mathrm{C} / \mathrm{P}$ & $\begin{array}{l}329 \\
(38)\end{array}$ & $\begin{array}{l}441 \\
(155)\end{array}$ & $\begin{array}{l}425 \\
(191)\end{array}$ & $\begin{array}{l}345 \\
(77)\end{array}$ & $\begin{array}{l}351 \\
(96)\end{array}$ & $\begin{array}{l}309 \\
(49)\end{array}$ & $\begin{array}{l}282 \\
(188)\end{array}$ \\
\hline
\end{tabular}

Mean (bold type) and standard deviation (in parentheses)

$\mathrm{n}=$ number of observations

Table 4

Cell maximum concentrations $\left(\mathrm{I}^{-1}\right)$ of Alexandrium minutum in 2004 and 2005 in the Penzé estuary.

\begin{tabular}{|c|c|c|c|c|c|c|c|}
\hline & 2004 & & & & 2005 & & \\
\hline Date & $6 / 06$ & $10 / 06$ & $14 / 06$ & $17 / 06$ & $9 / 06$ & $12 / 06$ & $15 / 06$ \\
\hline Cell I ${ }^{-1}$ & 8800 & 175700 & 215698 & 26412 & $\begin{array}{l}1160 \\
0\end{array}$ & 64000 & 454400 \\
\hline
\end{tabular}


Figure 1. Study area. (a) Main situation; (b) The Penzé estuary.
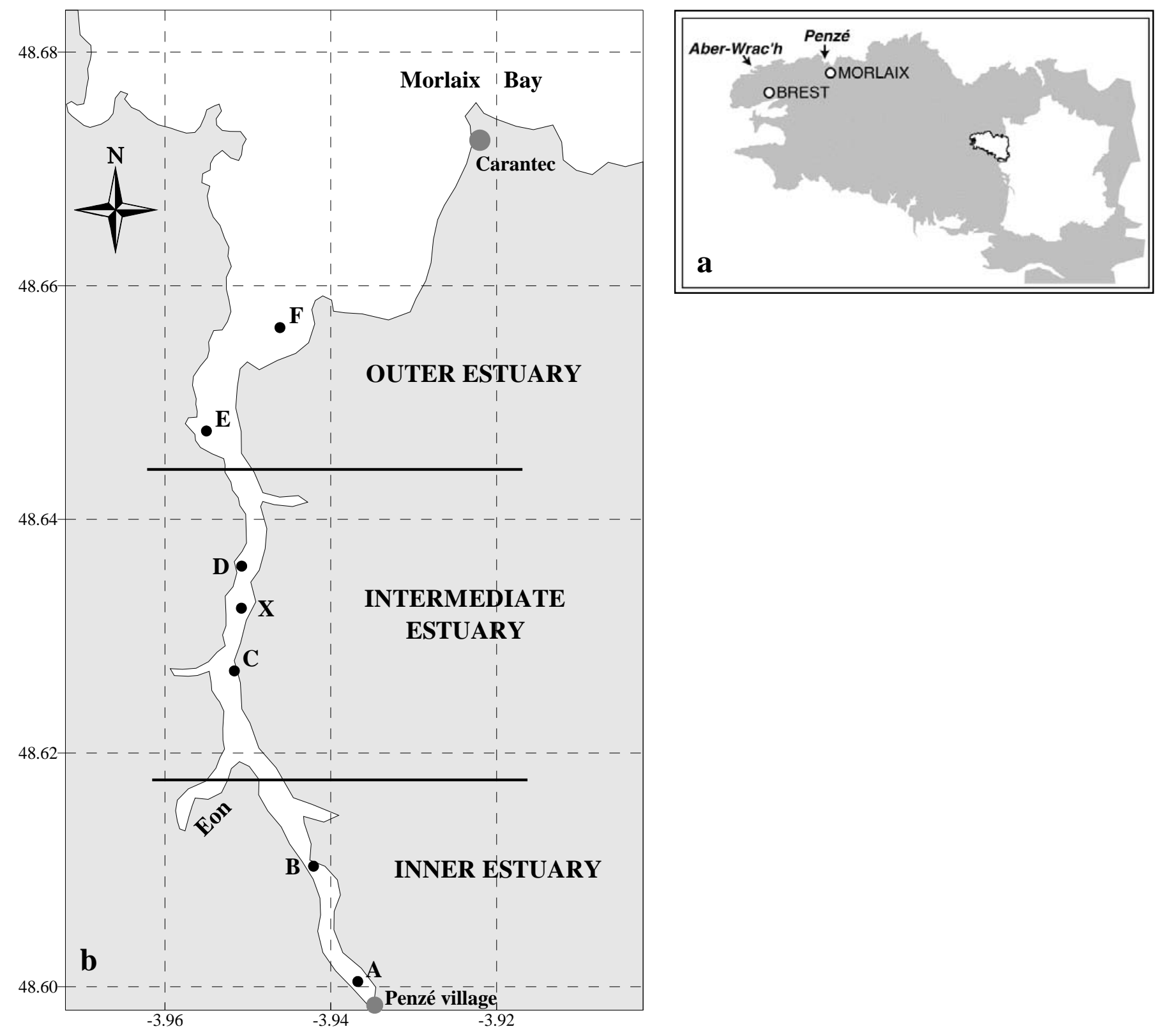
Figure 2. Vertical pore water profiles of the redox sensitive species, $\mathrm{O}_{2}(x), \mathrm{NO}_{3}^{-}(\bullet), \mathrm{Fe}^{2+}(\bullet), \mathrm{Mn}^{2+}(\Delta)$, along the Penzé estuary (2004-2005). Oxygen sensors were only available in March and June 2005. Scales are the same for every graph. Only tick marks are indicated for intermediate scales not to overload the figures.

December 2004

March 2005

June 2005

August 2004

$$
\mathrm{O}_{2}(\mathrm{X}), \mathrm{NO}_{3}^{-}(\bullet), \mathrm{Fe}^{2+}(\bullet) \quad \mu \mathrm{mol} \mathrm{l}^{-1}
$$
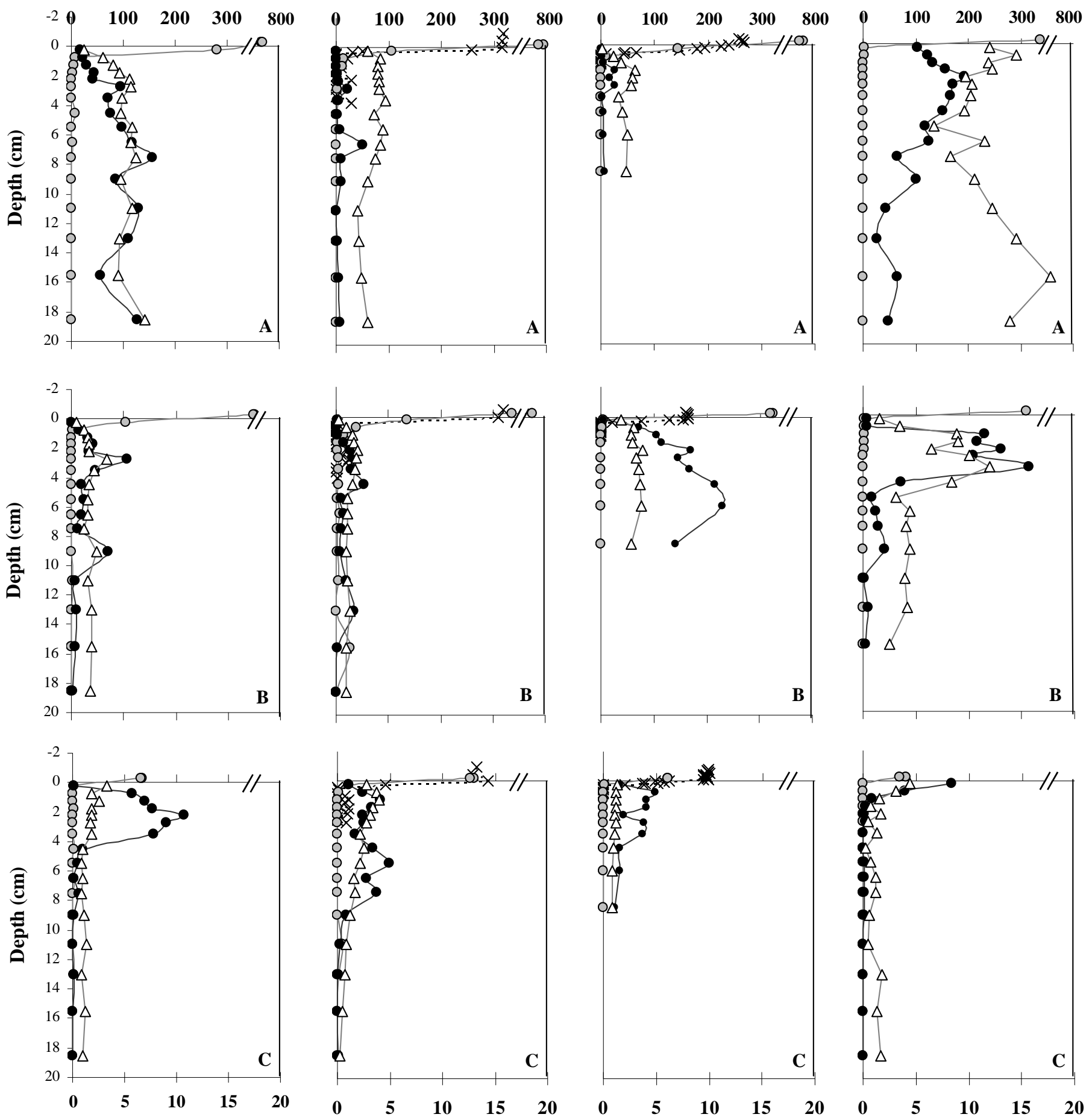

$$
\operatorname{Mn}^{2+}(\Delta) \quad \mu \mathrm{mol} \mathrm{I} \mathbf{l}^{-1}
$$


Figure 2 (continued)

December 2004

March 2005

June 2005

August 2004

$\mathrm{O}_{2}(\mathrm{X}), \mathrm{NO}_{3}^{-}(\bullet), \mathrm{Fe}^{2+}(\bullet) \quad \mathrm{mmol} \mathrm{l}^{-1}$
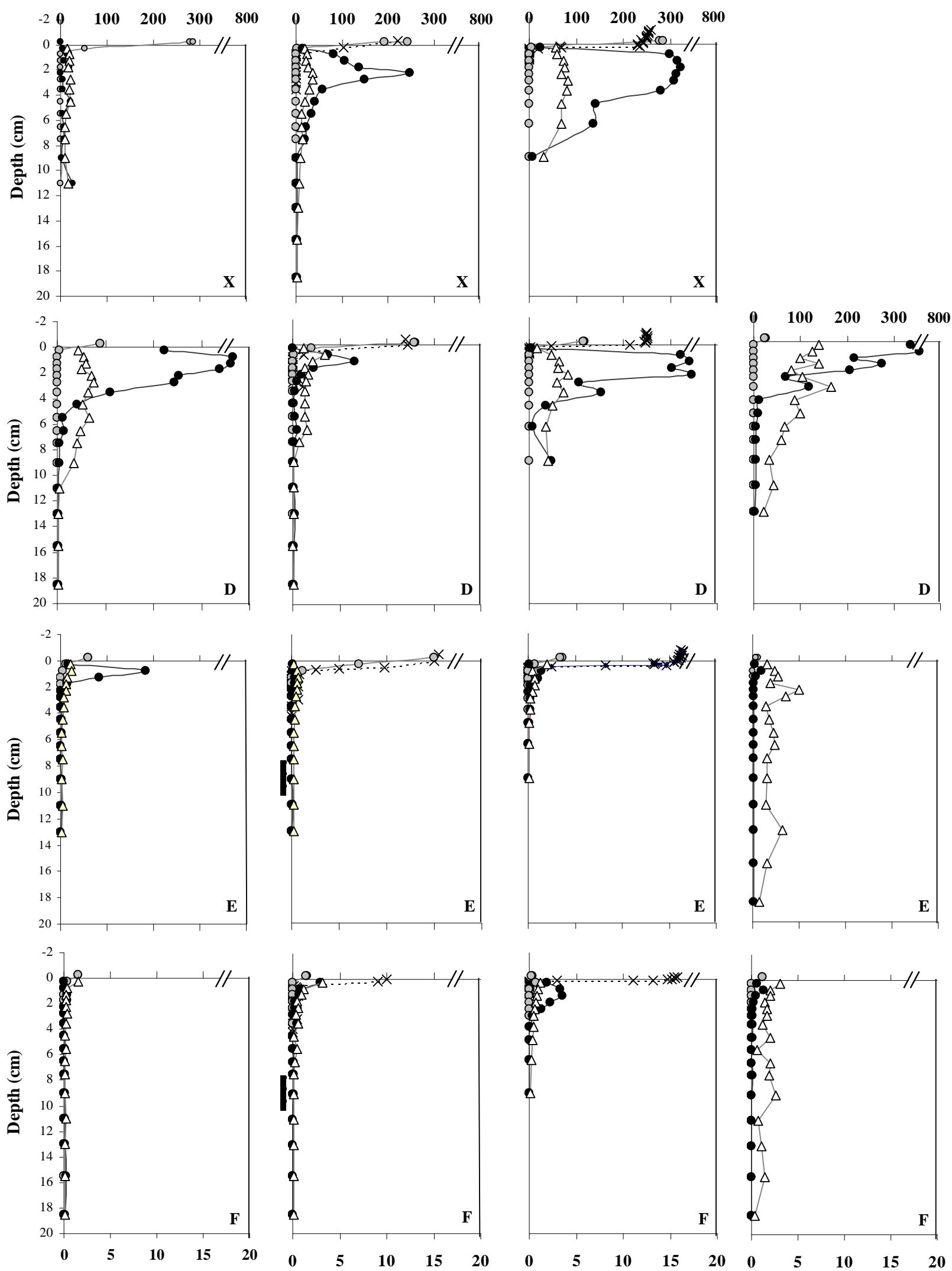

$\operatorname{Mn}^{2+}(\Delta) \quad \mu \mathrm{mol} \mathrm{I} \mathbf{l}^{-1}$ 
Figure 3. Vertical pore water profiles of $\mathrm{NH}_{4}^{+}(\bullet)$ and $\mathrm{PO}_{4}^{3-}(\Delta)$ along the Penzé estuary (2004-2005). Scales are the same for every graph. Only tick marks are indicated for intermediate scales not to overload the figures.

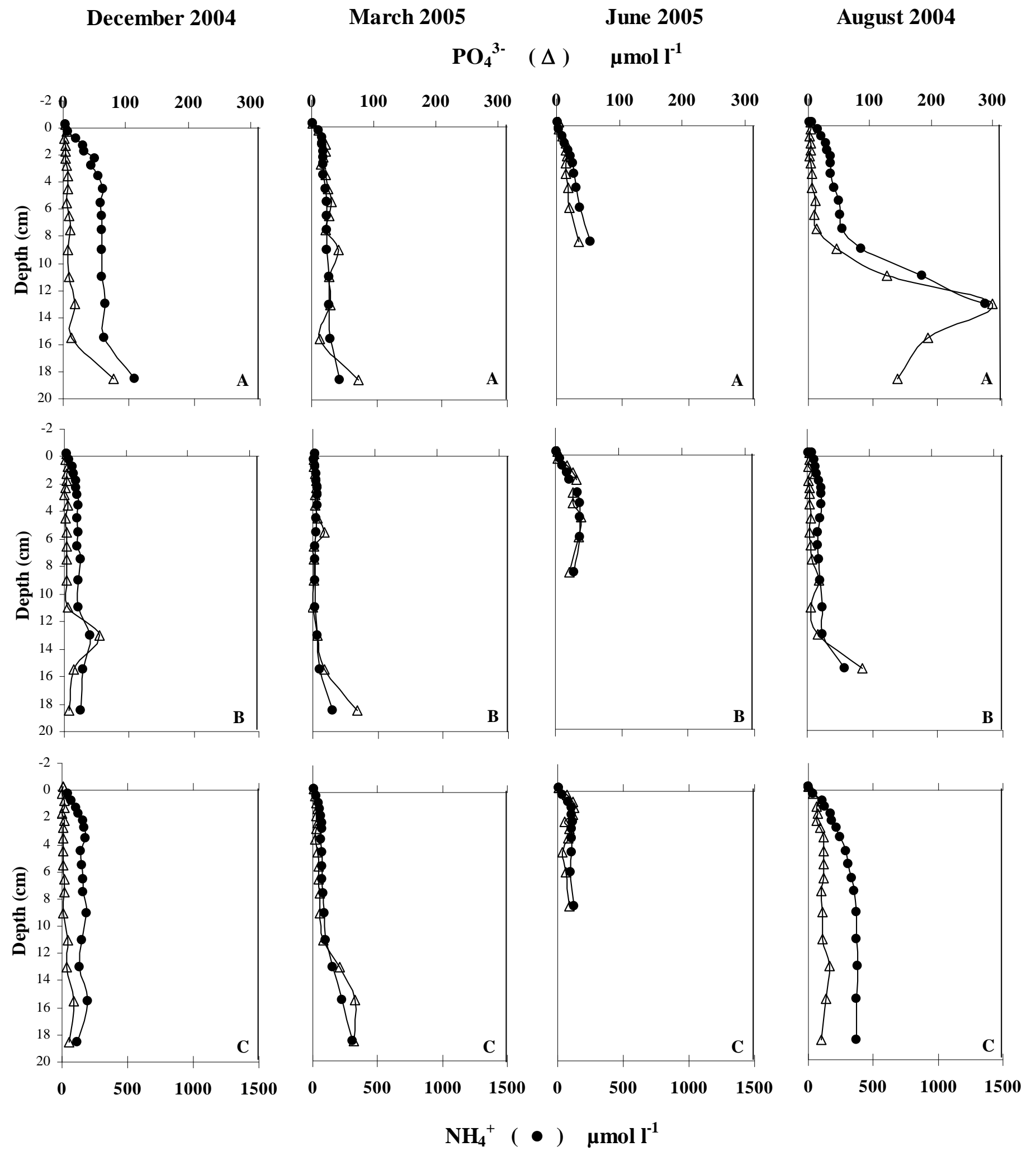




$$
\mathrm{PO}_{4}{ }^{3-}(\Delta) \quad \mu \mathrm{mol} \mathrm{I} \mathrm{I}^{-1}
$$
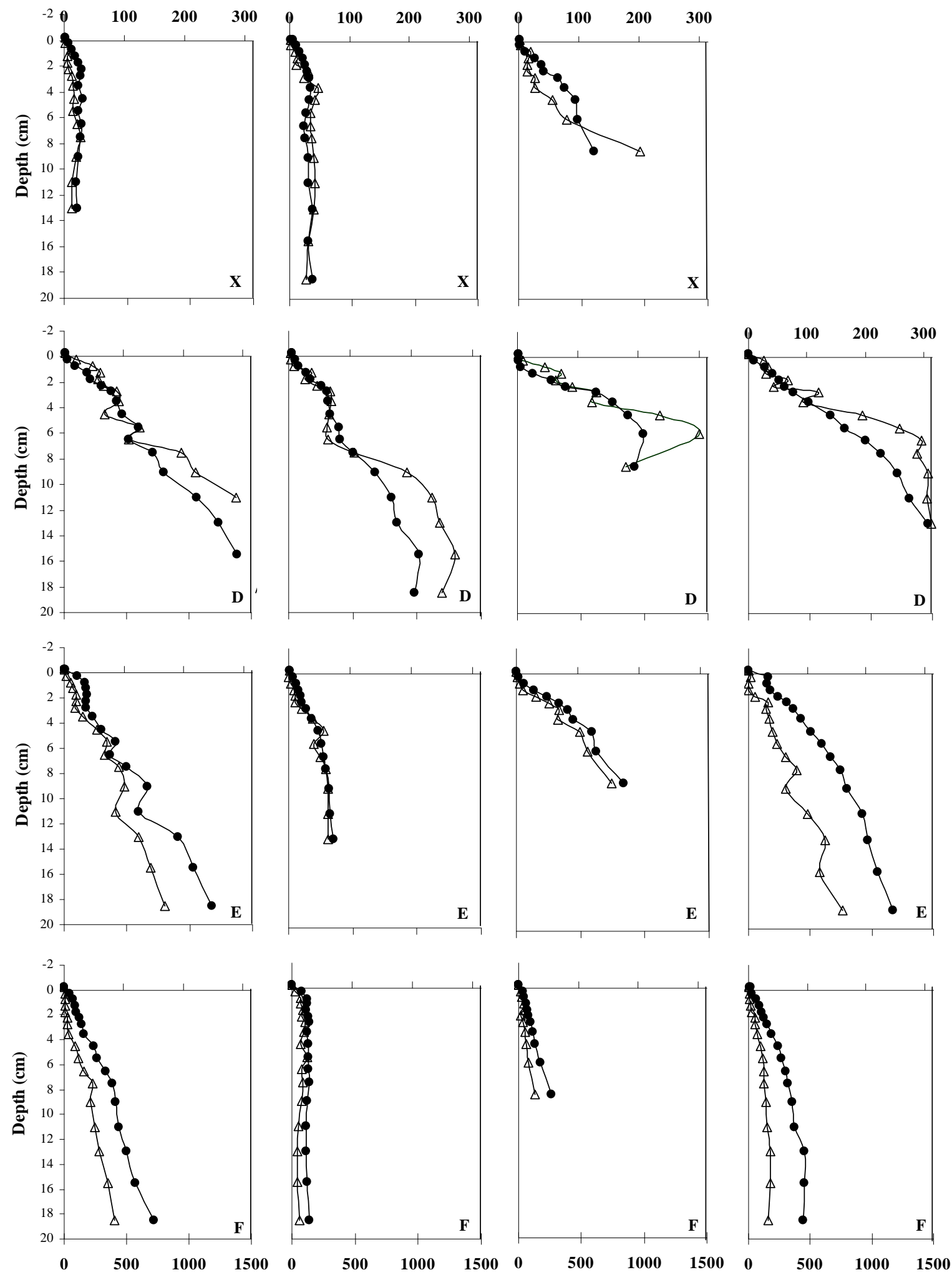

$\mathrm{NH}_{4}^{+}$( • ) $\mathrm{\mu mol} \mathrm{l}^{-1}$ 
Figure 4a. Vertical distributions of phosphorus forms in sediments of the Penzé inner estuary (2004-2005). Scales are the same for every graph. Only tick marks are indicated for intermediate scales not to overload the figures.

Figure 4b. Vertical distribution of phosphorus forms in sediments of the Penzé intermediate estuary (2004-2005). Scales are the same for every graph. Only tick marks are indicated for intermediate scales not to overload the figures.

Figure 4c. Vertical distribution of phosphorus forms in sediments of the Penzé outer estuary (2004-2005). Scales are the same for every graph. Only tick marks are indicated for intermediate scales not to overload the figures.

Figure 4a

INNER ESTUARY

\section{December 2004}

A

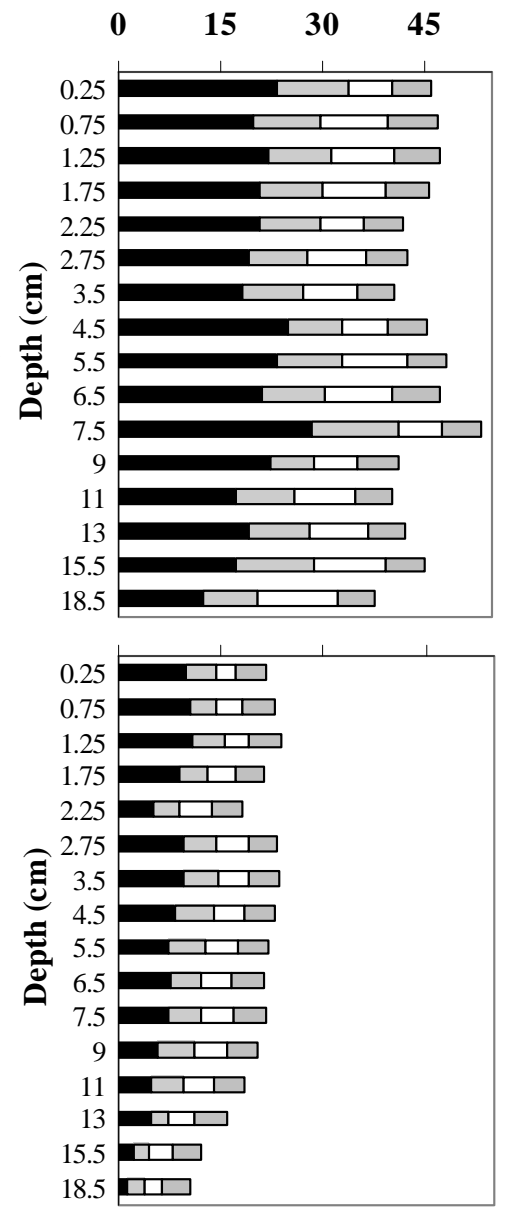

March 2005

Phosphonus forms ( $\mu \mathrm{mol} \mathrm{g}^{-1}$ )

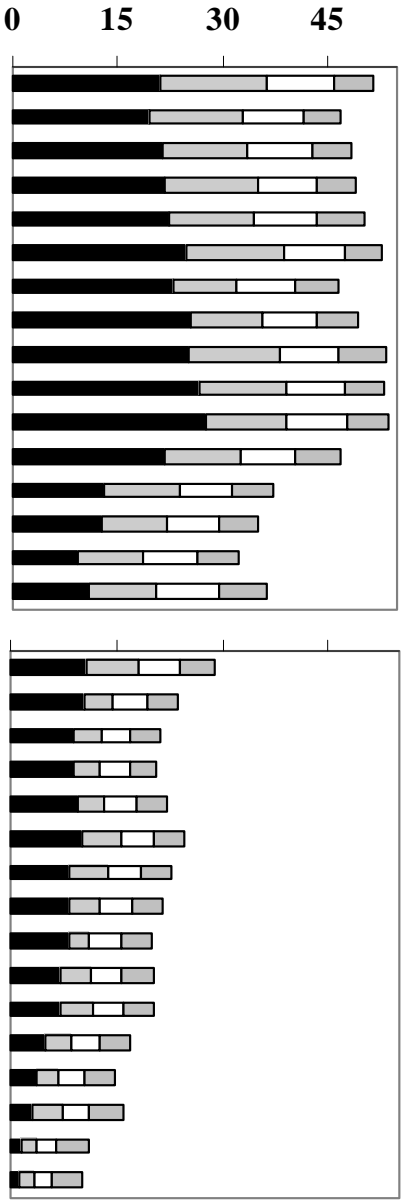

August 2004

June 2005
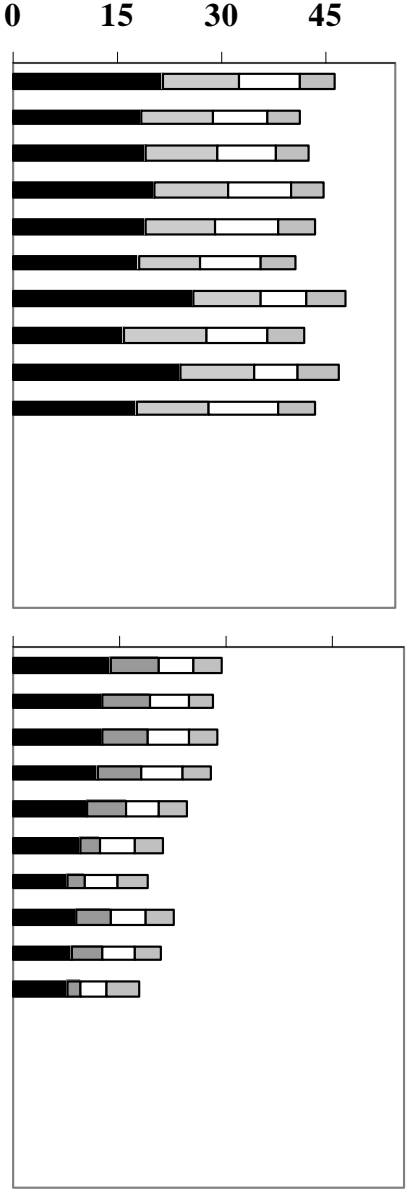

$\begin{array}{llll}0 & 15 & 30 & 45\end{array}$

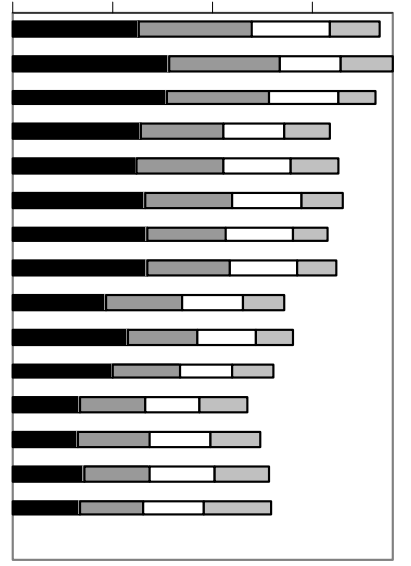

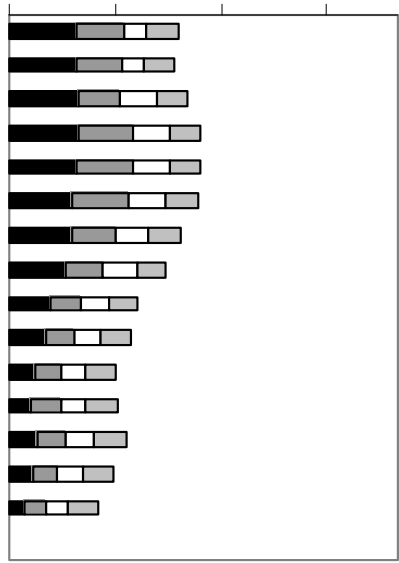

( $\square$ : Fe-P + Exch-P; $\square$ : Orga-P; $\square$ : Authigenic Ca-P; $\square$ : Detrital Ca-P ) 
Figure 4b

\section{INTERMEDIATE ESTUARY}

December 2004

\begin{tabular}{|c|c|c|c|}
\hline 0 & 15 & 30 & 45 \\
\hline 0.25 & पन & & \\
\hline 0.75 & صח & & \\
\hline 1.25 & صחب & & \\
\hline 1.75 & פוח & & \\
\hline 2.25 & שח & & \\
\hline 2.75 & صلم & & \\
\hline 3.5 & صبت & & \\
\hline 4.5 & سח & & \\
\hline 5.5 & שा" & & \\
\hline 6.5 & ש & & \\
\hline 7.5 & ل1م & & \\
\hline 9 & שח & & \\
\hline 11 & 11 & & \\
\hline 13 & 正 & & \\
\hline 15.5 & III & & \\
\hline 18.5 & שـ & & \\
\hline
\end{tabular}

\section{$0.25=$}

0.75 पाप

1.25 שा

1.75 שा

2.25 שח

हี 2.75 पा

$\mathrm{X}$

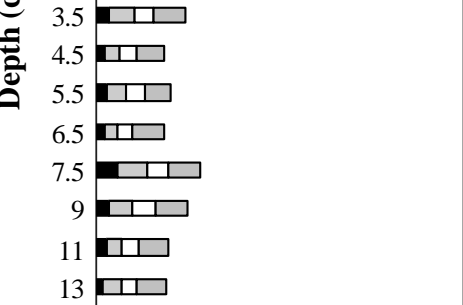

$0.25 \stackrel{1}{0.75}$

0.75 מדב

1.25 בדב

1.75 בדב

2.25 מבדי

2.75 שיח

שבח 3.5

D

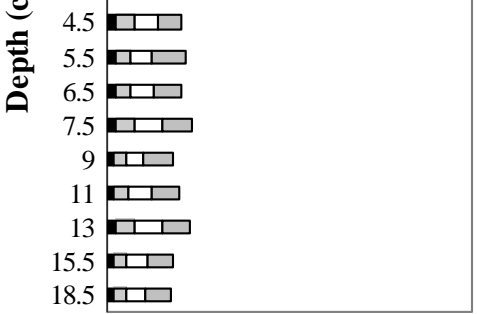

June 2005

Phosphorus forms ( $\mu \mathrm{mol} \mathrm{g}^{-1}$ )

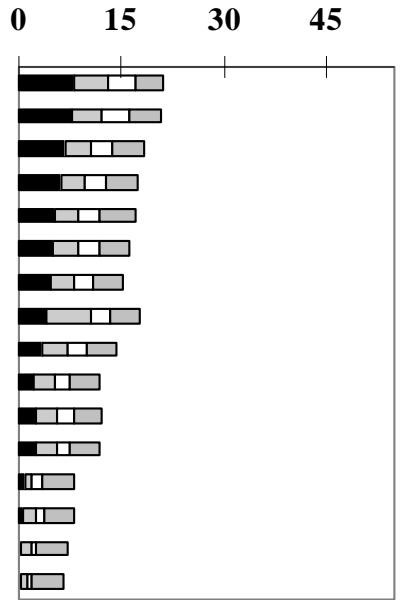

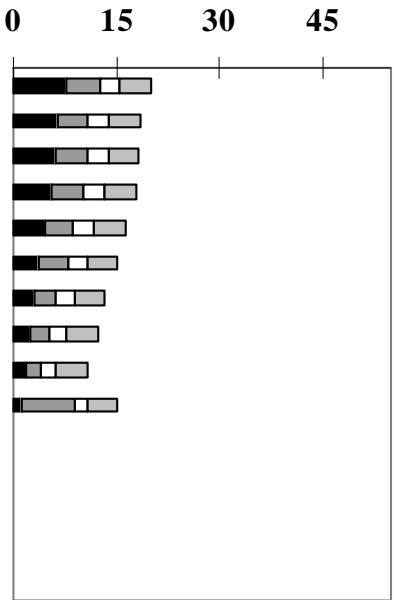

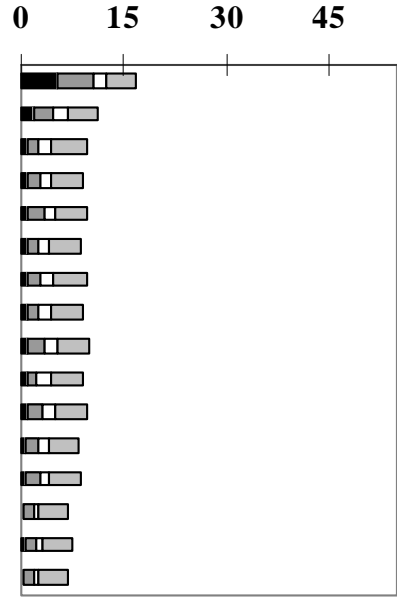

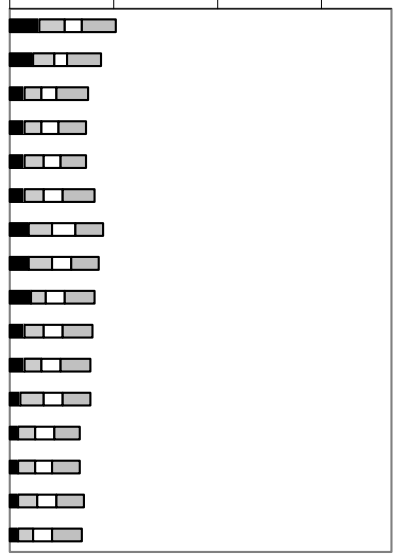
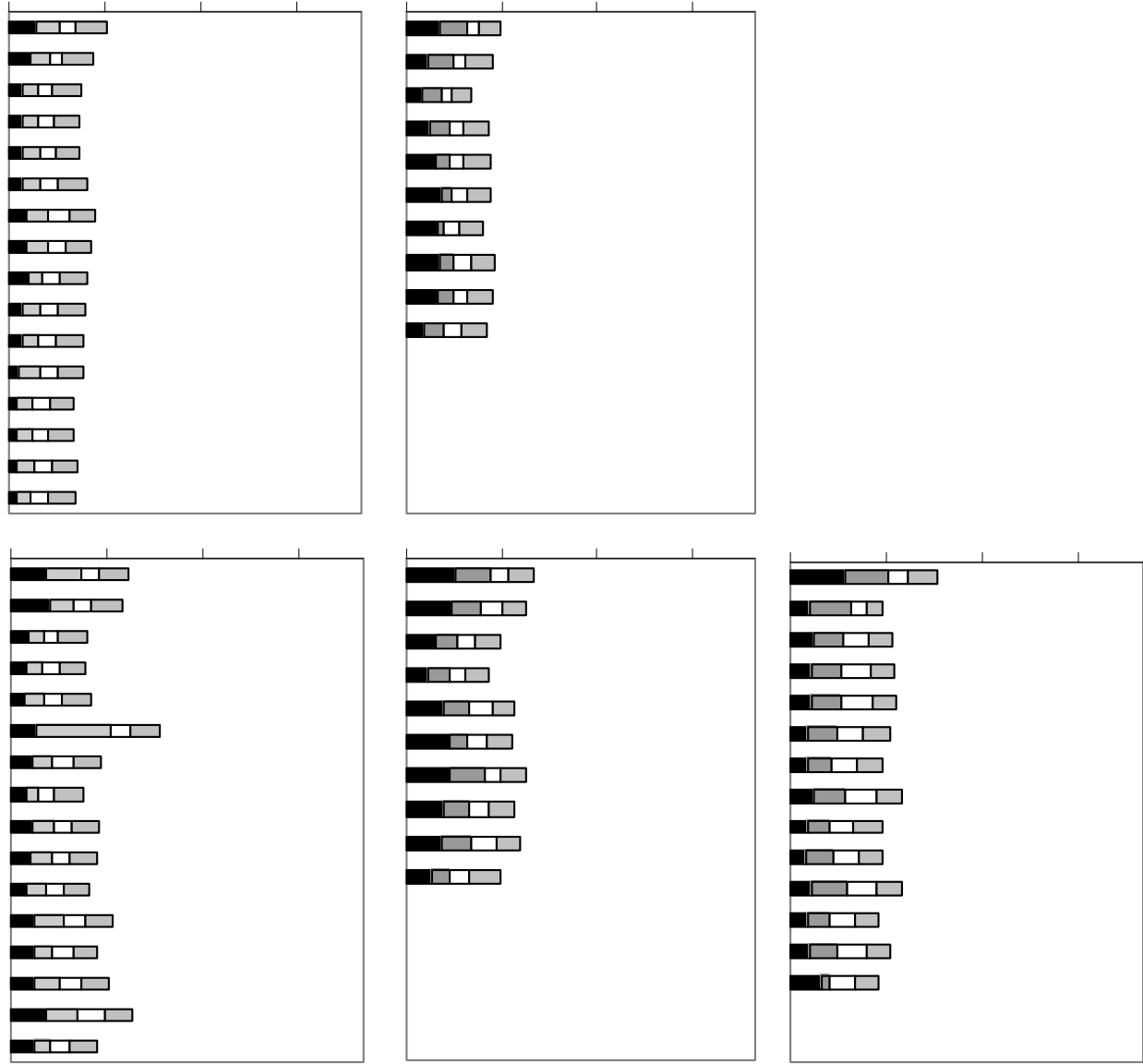

( $\square$ : Fe-P + Exch-P; $\square$ : Orga-P; $\square$ : Authigenic Ca-P; $\square$ : Detrital Ca-P ) 
Figure 4c

\section{OUTER ESTUARY}

December 2004

March 2005

Phosphorus forms $\left(\mu \mathrm{mol} \mathrm{g}^{-1}\right)$

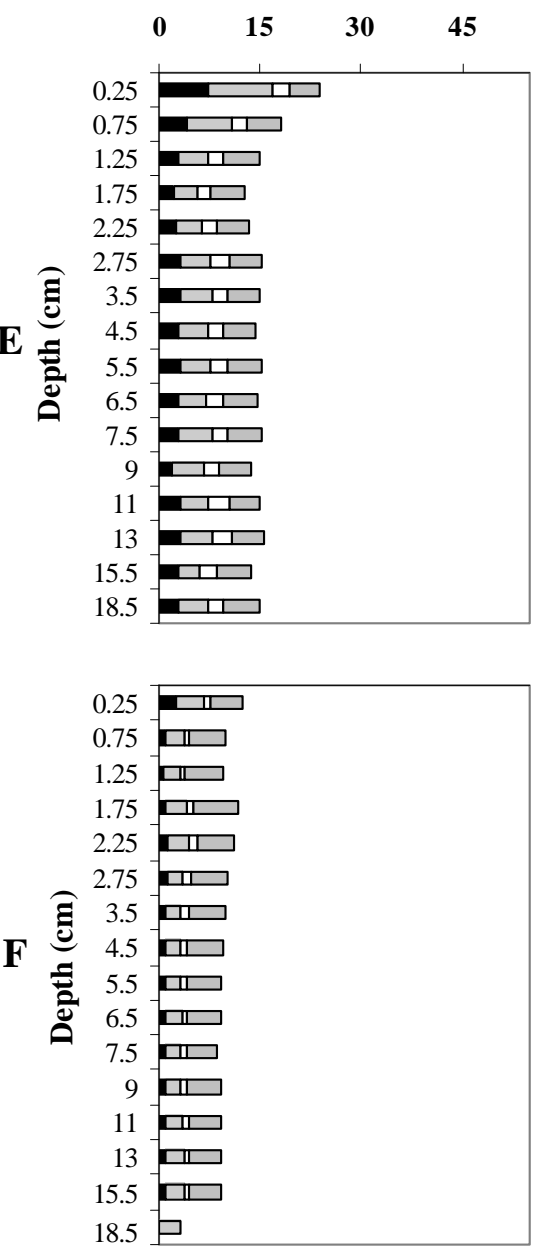

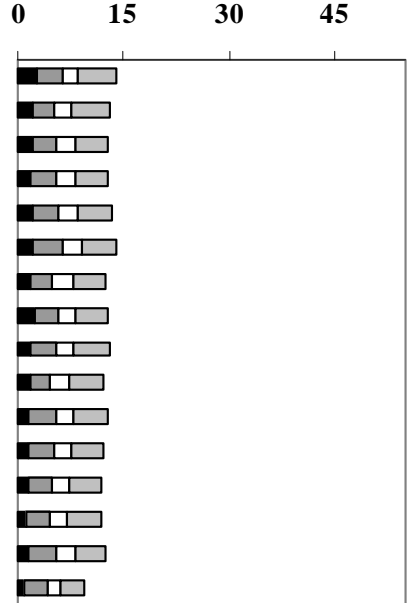

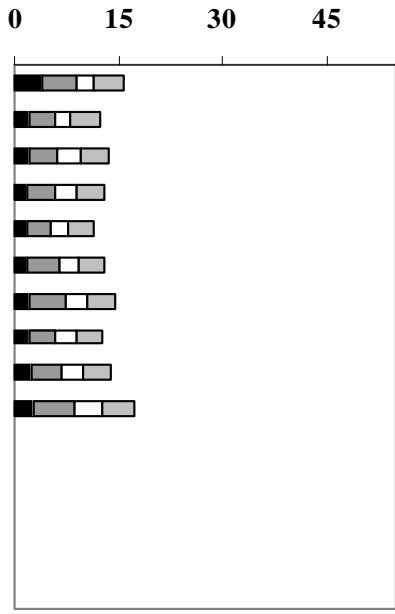

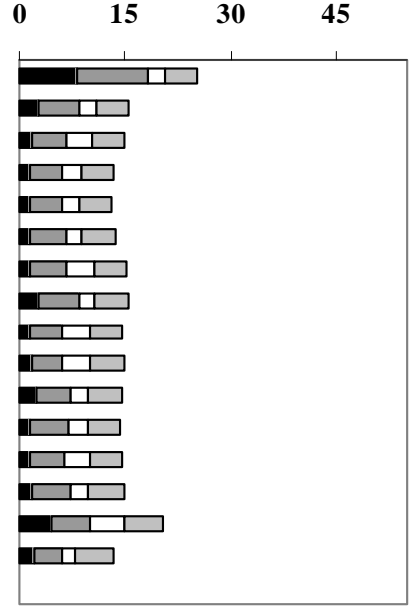

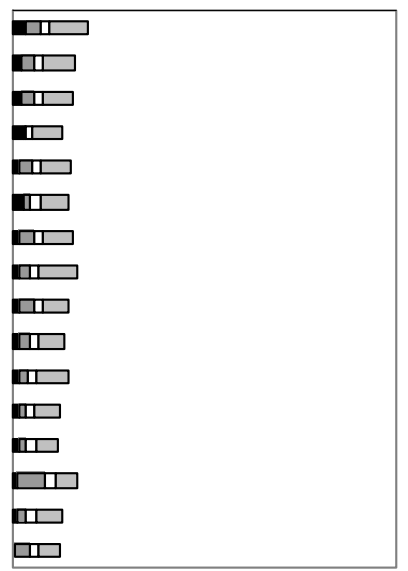

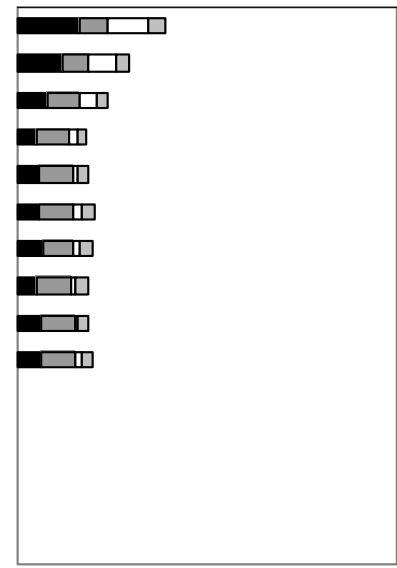

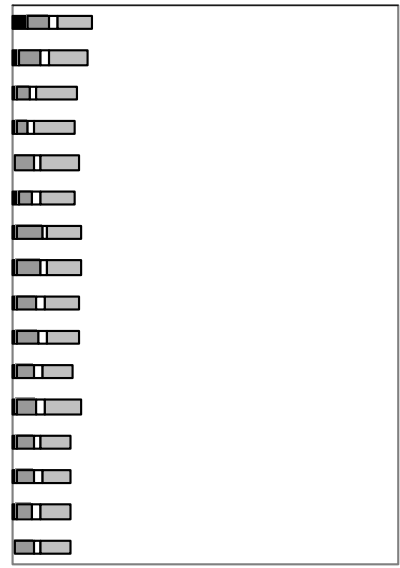

( $\square$ : Fe-P + Exch-P; $\square$ : Orga-P; $\square$ : Authigenic Ca-P; $\square$ : Detrital Ca-P ) 
Figure 5. Exchangeable phosphate $($ Exch-P) in surficial sediments $(0-0.5 \mathrm{~cm})$ along the Penzé estuary (20042005).

Figure 5

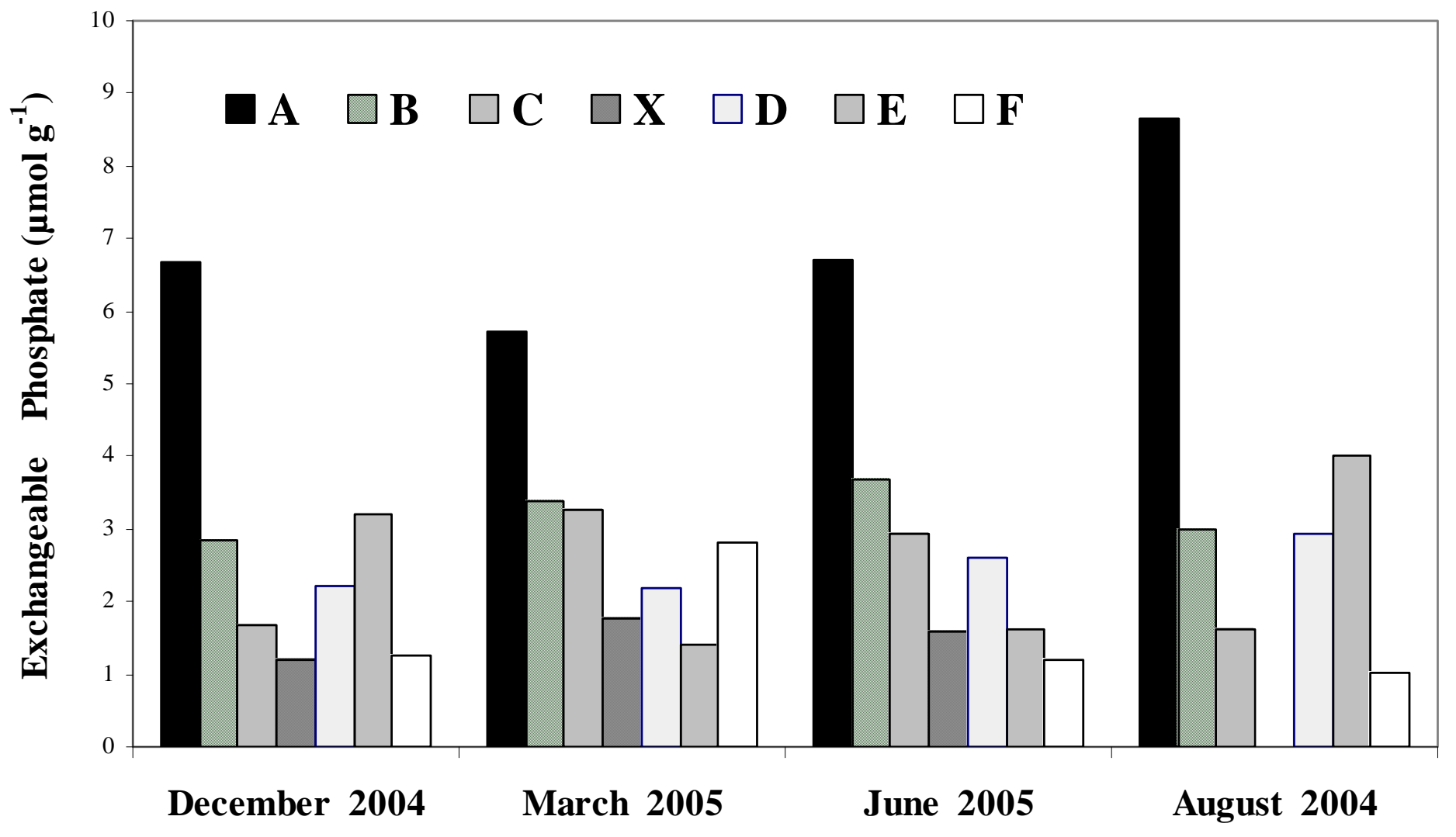


Figure 6. Particulate Fe/P ratios in oxic surficial sediments $(0-0.5 \mathrm{~cm})$ along the Penzé estuary (December 2004, March 2005, June 2005 and August 2004). The Fe/P ratios under the dashed line (Fe/P = 8) suggest saturation of sorption sites.

Figure 6

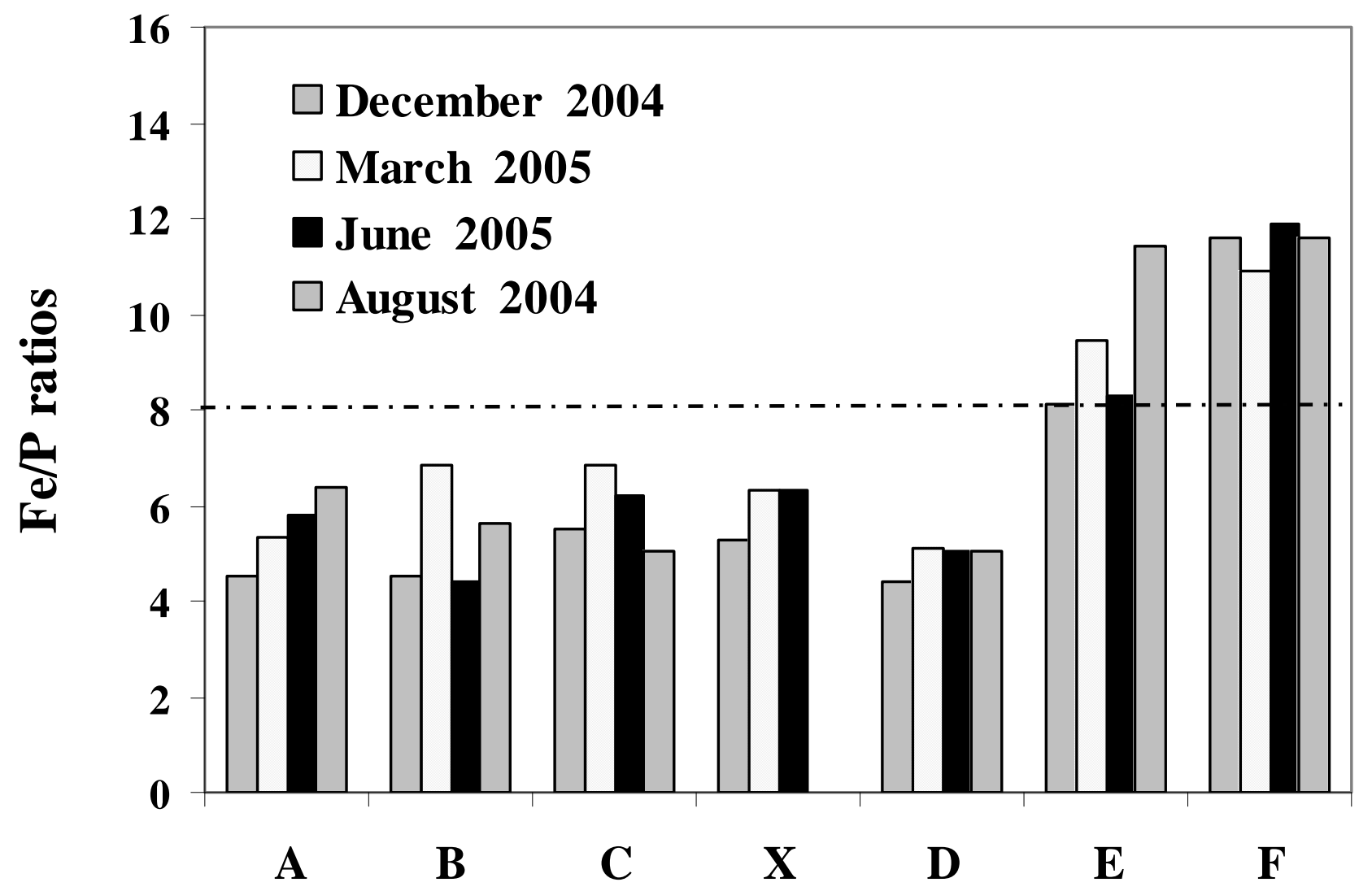


Figure 7. Phosphate diffusive flux $\left(\mu \mathrm{mol} \mathrm{m} \mathrm{m}^{-2} \mathrm{~d}^{-1}\right)$ and Alexandrium Minutum cell maximum densities (cell $\mathrm{I}^{-1}$ ) in the Penzé intermediate estuary (st X), in May, June and July 2003. Flux evaluations were duplicated in May and July (core 1 and 2).

Figure 7

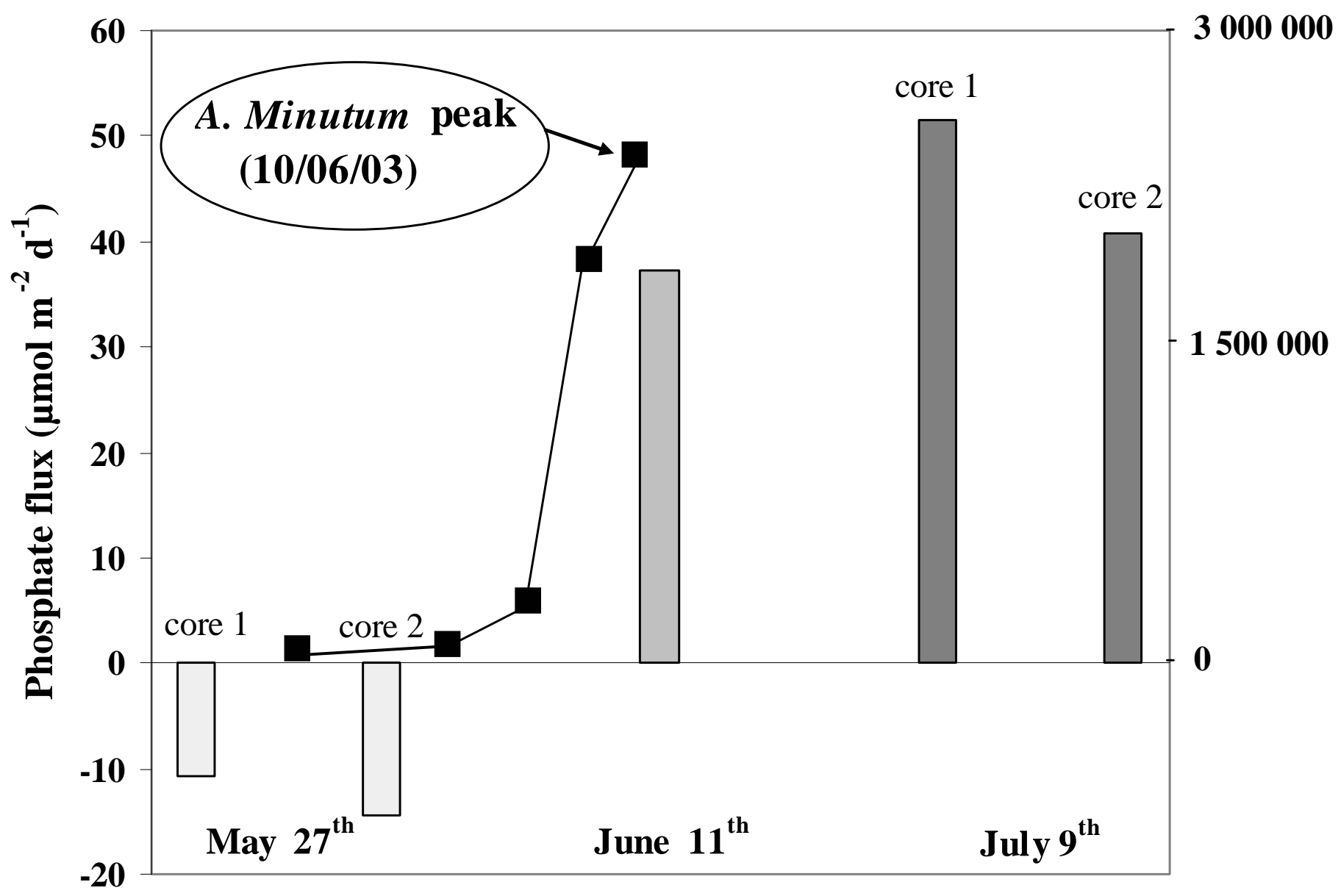


Figure 8. Phosphate diffusive flux $\left(\mu \mathrm{mol} \mathrm{m} \mathrm{m}^{-2} \mathrm{~d}^{-1}\right)$ along the Penzé estuary (2004-2005).

\section{Figure 8}

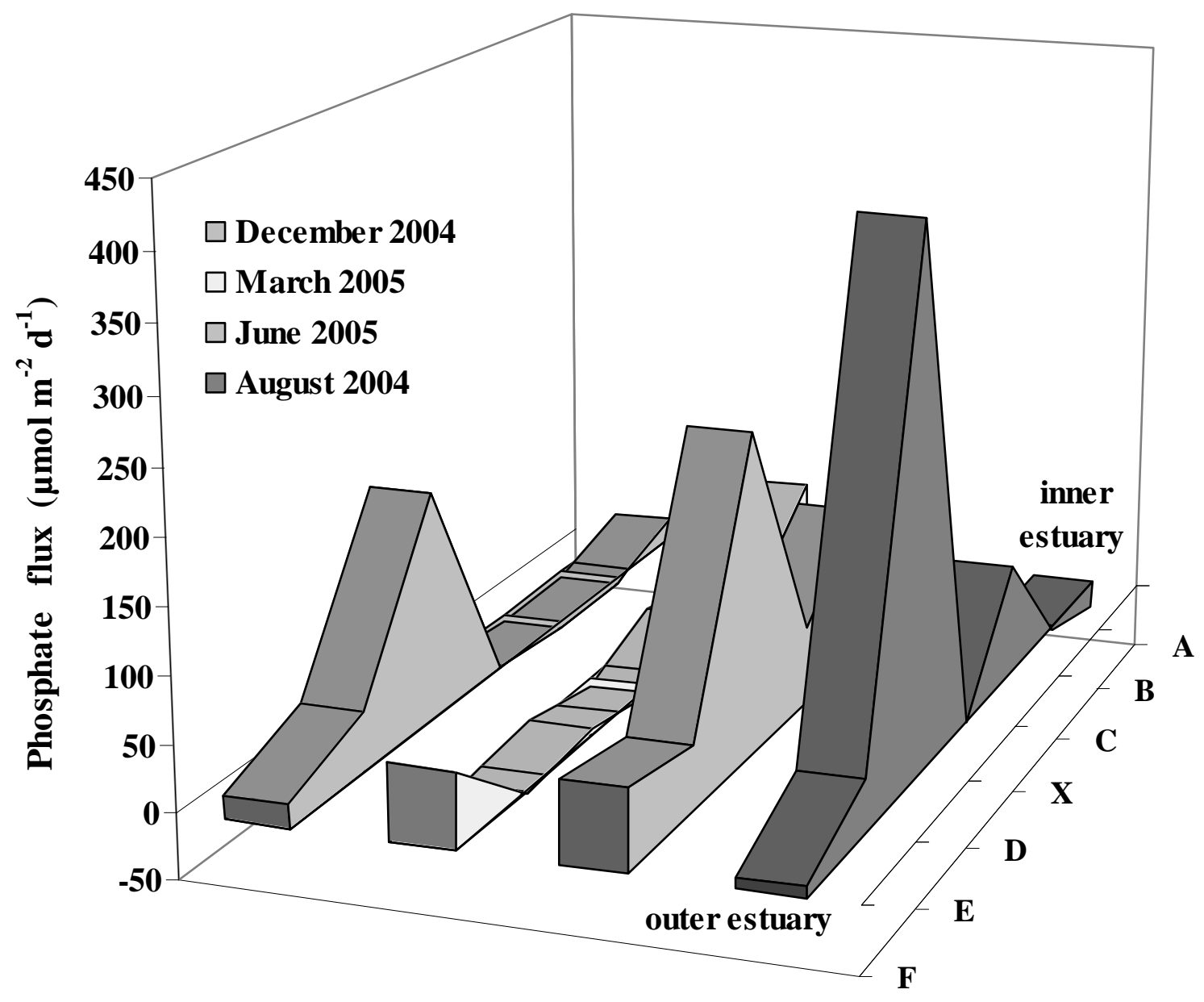

